\title{
HIV-Associated Apathy/Depression and Neurocognitive Impairments Reflect Persistent Dopamine Deficits
}

\author{
Kristen A. McLaurin ${ }^{\dagger}$, Michael Harris ${ }^{\dagger}$, Victor Madormo $^{\dagger}$, Steven B. Harrod, Charles F. Mactutus \\ and Rosemarie M. Booze *D
}

Citation: McLaurin, K.A.; Harris, M.; Madormo, V.; Harrod, S.B.; Mactutus, C.F.; Booze, R.M. HIV-Associated Apathy/Depression and Neurocognitive Impairments Reflect Persistent Dopamine Deficits. Cells 2021, 10, 2158. https://doi.org/ $10.3390 /$ cells 10082158

Academic Editor: Eliseo Eugenin

Received: 6 July 2021

Accepted: 18 August 2021

Published: 21 August 2021

Publisher's Note: MDPI stays neutral with regard to jurisdictional claims in published maps and institutional affiliations.

Copyright: (c) 2021 by the authors. Licensee MDPI, Basel, Switzerland. This article is an open access article distributed under the terms and conditions of the Creative Commons Attribution (CC BY) license (https:/ / creativecommons.org/licenses/by/ $4.0 /)$.
Department of Psychology, University of South Carolina, Columbia, SC 29208, USA; mclaurik@email.sc.edu (K.A.M.); mwh2@email.sc.edu (M.H.); vmadormo@email.sc.edu (V.M.); harrods@mailbox.sc.edu (S.B.H.); mactutus@mailbox.sc.edu (C.F.M.)

* Correspondence: booze@mailbox.sc.edu

+ These authors contributed equally.

Abstract: Individuals living with human immunodeficiency virus type 1 (HIV-1) are often plagued by debilitating neurocognitive impairments and affective alterations; the pathophysiology underlying these deficits likely includes dopaminergic system dysfunction. The present review utilized four interrelated aims to critically examine the evidence for dopaminergic alterations following HIV-1 viral protein exposure. First, basal dopamine (DA) values are dependent upon both brain region andexperimental approach (i.e., high-performance liquid chromatography, microdialysis or fast-scan cyclic voltammetry). Second, neurochemical measurements overwhelmingly support decreased DA concentrations following chronic HIV-1 viral protein exposure. Neurocognitive impairments, including alterations in pre-attentive processes and attention, as well as apathetic behaviors, provide an additional line of evidence for dopaminergic deficits in HIV-1. Third, to date, there is no compelling evidence that combination antiretroviral therapy (cART), the primary treatment regimen for HIV-1 seropositive individuals, has any direct pharmacological action on the dopaminergic system. Fourth, the infection of microglia by HIV-1 viral proteins may mechanistically underlie the dopamine deficit observed following chronic HIV-1 viral protein exposure. An inclusive and critical evaluation of the literature, therefore, supports the fundamental conclusion that long-term HIV-1 viral protein exposure leads to a decreased dopaminergic state, which continues to persist despite the advent of cART. Thus, effective treatment of HIV-1-associated apathy/depression and neurocognitive impairments must focus on strategies for rectifying decreases in dopamine function.

Keywords: dopamine; HIV-1; combination antiretroviral therapy; pre-pulse inhibition; attention; apathy; microglia; dendritic spines

\section{Introduction}

Since the beginning of the acquired immunodeficiency syndrome (AIDS) epidemic, neurocognitive impairments (NCI) and affective alterations have been associated with the disease [1,2]. Early in the AIDS epidemic, underlying focal processes and opportunistic infections accounted for approximately 30\% of the neurological complications in individuals with AIDS; a progressive dementia, however, was more commonly reported [3]. The identification of human immunodeficiency virus type 1 (HIV-1) as the retroviral etiology of AIDS [4,5] led to the hypothesis that NCI and affective alterations may result from the direct effect of the virus on the brain. Indeed, HIV-1 penetrates the central nervous system (CNS) early in the course of infection [6], evidenced by the presence of HIV-1 in postmortem brain tissue [7-9], findings which led to the characterization of this progressive dementia, which became known as AIDS dementia complex (ADC, also recognized as HIV-associated dementia (HAD)).

ADC, which afflicted approximately $66 \%$ of autopsy-verified AIDS patients early in the epidemic, was a neurological syndrome primarily occurring during the later phases of 
systemic AIDS [3]. Early clinical characteristics of ADC included NCI (e.g., forgetfulness, loss of concentration), affective alterations (e.g., apathy) and motor system deficits $[3,10,11]$. Across time, most patients with ADC exhibited a steady decline in neurocognitive function, leading to severe dementia, ataxia and motor weakness [10].

Pathologically, distinct abnormalities in the white matter and subcortical structures, including the basal ganglia, were observed in the brains of individuals with ADC [12], observations which led researchers to hypothesize dopaminergic system dysfunction as a potential mechanism underlying the disease [13]. Cerebrospinal fluid (CSF) levels of dopamine (DA [14,15]) and homovanillic acid (HVA [15-17]), the primary DA metabolite, were significantly reduced in HIV-1/AIDS patients relative to seronegative controls. In HIV-1-infected brains, significant reductions in tyrosine hydroxylase (TH), the rate-limiting enzyme of DA synthesis, were also observed [18]. Most critically, the relationship between CSF HVA levels and neuropsychological function in HIV-1-infected patients provided compelling evidence for the role of dopaminergic system dysfunction in the pathogenesis of ADC [17].

With the discovery and introduction of antiretroviral therapies, however, AIDS/HIV-1 became a chronic, manageable disease, albeit NCI and affective alterations persist. The development of zidovudine (azidothymidine [19]), the first generation of antiretroviral therapy, provided early evidence that effective inhibition of HIV-1 may have some effects on cognitive function in AIDS patients [20-22]. Zidovudine monotherapy did not, however, mitigate affective alterations [20]. The subsequent utilization of multiple antiretroviral compounds to treat HIV-1 (i.e., combination antiretroviral therapy (cART)) led to a dramatic decrease in the severity of NCI and affective alterations associated with HIV-1 [23]. Specifically, in the post-cART era, ADC is rare, afflicting only 2-8\% of cART-treated HIV-1 seropositive individuals [23]. However, milder forms of NCI and affective alterations persist, afflicting between $30 \%$ and $70 \%$ of HIV-1 seropositive individuals [24-27].

Although the pathophysiology of HAND and affective alterations in the post-cART era is likely multidimensional, dopaminergic system dysfunction persists [28-30]. Using four interrelated aims, the present review will examine evidence for alterations in dopaminergic levels in HIV-1 in the post-cART era. Given that approximately 73\% of HIV-1 seropositive individuals are currently accessing antiretroviral treatment [31], the present review focuses on studies using biological systems (i.e., HIV-1 seropositive individuals, primates, rats, mice) with viral suppression. First, we will report basal/tonic values of DA in the CNS, including a discussion of the experimental approaches (e.g., high-performance liquid chromatography (HPLC), microdialysis, fast-scan cyclic voltammetry (FSCV)) used to measure DA. Second, the present review will examine the prominent evidence, including both anatomical and clinical symptomology, for the persistent decreased dopamine in HIV-1 seropositive individuals. Third, the potential effects of cART on the dopaminergic system will be assessed. Finally, we will address the mechanistic implications for dopamine decreases in HAND.

\section{Basal Dopamine Concentrations in the Central Nervous System}

The physiological significance of DA [32], and its presence in the brain [33-35], was first established in the 1950s. Subsequent methodological advances, including the development of microdialysis, HPLC and FSCV, afforded a critical opportunity to detect changes in basal (or tonic) DA [36]. However, DAs precise influence on cognition and behavior remains unclear, in large part due to inconsistencies in measured DA levels. Thus, one of the primary goals was to illustrate the inconsistencies in values via examination of the standard error of the mean and relative standard error.

DA concentration was estimated using the reported means, which were converted into ng/g of tissue (Table 1). Reported estimates are collapsed across species and biological sex under the assumption that the variability between brain regions and methodological approach are greater than the variability between species and sex [37]. Each manuscript, therefore, provided a single observation for each brain region that was reported. All 
estimates, as well as information regarding species and biological sex, are reported in Supplementary Table S1.

Critical evaluation of the literature revealed that basal DA values are dependent upon not only brain region, but also methodological technique (between-subjects ANOVA with log estimated DA concentration in $\mathrm{ng} / \mathrm{g}$ of tissue as the dependent variable: brain region by method interaction, $F(5,104)=7.05, p \leq 0.001, \eta_{p}{ }^{2}=0.253$; Table 1; Figure 1). For example, utilization of HPLC to measure DA in the nucleus accumbens (NAc) results in an average estimated DA concentration over 40,000 times greater than the average estimated DA concentration measured using microdialysis. This outcome might be anticipated due to tissue homogenization prior to HPLC measurement; HPLC, therefore, measures total tissue DA content, whereas microdialysis measures extracellular DA levels [38]. Additionally, substantial variability in reported basal DA values within a single methodological approach was observed. For example, the relative standard error for the NAc was $33.9 \%, 17.1 \%$ and $27.8 \%$ for HPLC, microdialysis and FSCV respectively, values which are even higher in other brain regions (e.g., amygdala: 84.1\% (HPLC) and 50\% (microdialysis)). Given the substantial variability within and between methodological techniques, a brief discussion of some of the critical experimental considerations underlying these discrepancies is warranted. In addition, the potential utility of the latest technology (i.e., $G$ protein-coupled receptor (GPCR) biosensors) for monitoring DA release is briefly reviewed.

Table 1. Estimated basal dopamine (DA) values. Abbreviations: High Performance Liquid Chromatogrphy (HPLC); Fast Scan Cyclic Voltammetry (FSCV).

\begin{tabular}{|c|c|c|c|c|}
\hline Brain Region & Methodology & $\begin{array}{c}\text { Estimated DA } \\
\text { Concentration in } \mathrm{ng} / \mathrm{g} \\
\text { of Tissue } \\
(\mathrm{X} \pm \mathrm{SEM})\end{array}$ & $\begin{array}{l}\text { Relative Standard } \\
\text { Error }\end{array}$ & References \\
\hline \multirow{2}{*}{ Amygdala } & HPLC & $3683.85 \pm 3097$ & $84.1 \%$ & [39-43] \\
\hline & Microdialysis & $0.06 \pm 0.03$ & $50 \%$ & [44-47] \\
\hline \multirow{2}{*}{ Caudate } & HPLC & $16,365.9 \pm 12,341.04$ & $75.4 \%$ & {$[28,39,41,48-54]$} \\
\hline & Microdialysis & $0.88 \pm 0.66$ & $75 \%$ & {$[44,55,56]$} \\
\hline \multirow{2}{*}{ Frontal Cortex } & HPLC & $200.73 \pm 84.41$ & $42.1 \%$ & {$[28,39,42,52,54,57-62]$} \\
\hline & Microdialysis & $0.23 \pm 0.10$ & $43.5 \%$ & {$[44,63-65]$} \\
\hline \multirow{3}{*}{ Nucleus Accumbens } & HPLC & $35,772.90 \pm 12,020.28$ & $33.6 \%$ & {$[41-43,51,52,57,59,60,62,66-68]$} \\
\hline & Microdialysis & $0.76 \pm 0.13$ & $17.1 \%$ & {$[44,45,47,55,63-65,67-99]$} \\
\hline & FSCV & $6.95 \pm 1.93$ & $27.8 \%$ & [100-104] \\
\hline \multirow{2}{*}{ Striatum } & HPLC & $67,460.52 \pm 29,013.28$ & $43 \%$ & {$[59,61,62,66,67,105-111]$} \\
\hline & Microdialysis & $1.42 \pm 0.40$ & $28.2 \%$ & {$[64,73,74,76,79,82,85,112-114]$} \\
\hline \multirow{2}{*}{ Ventral Tegmental Area } & HPLC & 9200 & & {$[66]$} \\
\hline & Microdialysis & $0.25 \pm 0.07$ & $28 \%$ & {$[75,83]$} \\
\hline
\end{tabular}

\subsection{High-Performance Liquid Chromatography (HPLC)}

Broadly, chromatography is a well-established separative and analytical technique introduced by James and Martin [115]; the emergence of HPLC, however, is attributed to Huber and Hulsman [116]. To conduct HPLC, a pressurized liquid solvent (i.e., mobile phase) containing the sample is passed through a column filled with a solid adsorbent material, and each compound elutes at a unique rate, resulting in the separation of components as they flow through the column [117]. The isolated compounds are subsequently identified and quantified using a detector (e.g., UV/Vis spectrometry). HPLC can be further subdivided into multiple types dependent upon the type of column (e.g., liquidliquid, ion-exchange, size exclusion) and "mobile phase" (e.g., non-polar, polar), factors which influence sensitivity, resolution and the method of brain tissue extraction. Critically, 
differences in extraction methodology (e.g., time of initial extraction, aqueous $\mathrm{pH}$ value, extraction solvents) result in drastic differences in percent recovery, an indirect measure of basal DA concentration [118].

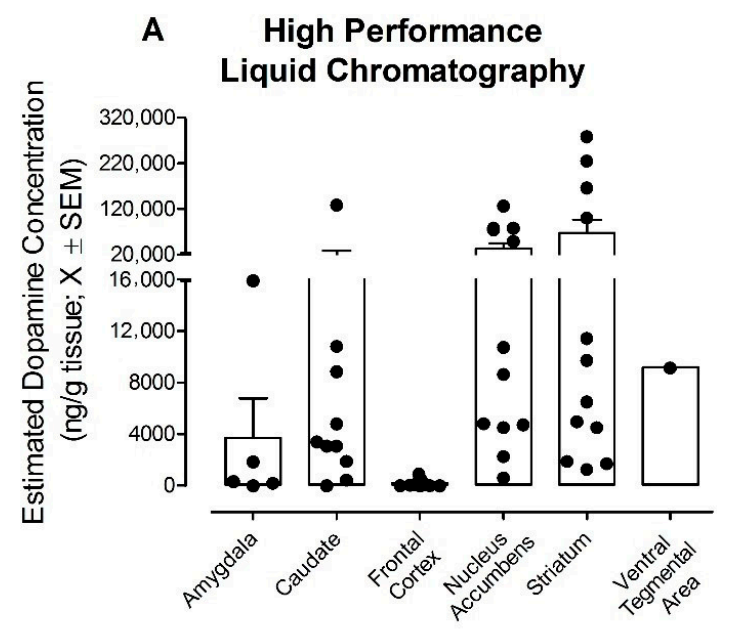

B Microdialysis

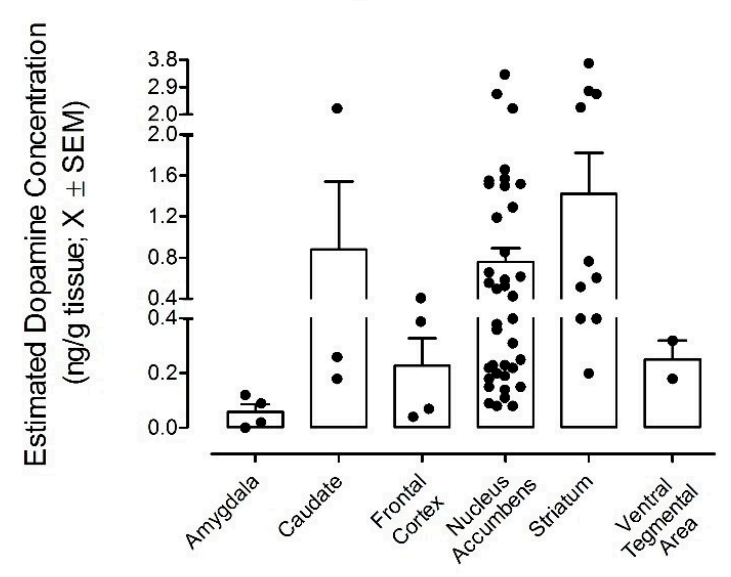

C

Fast Scan

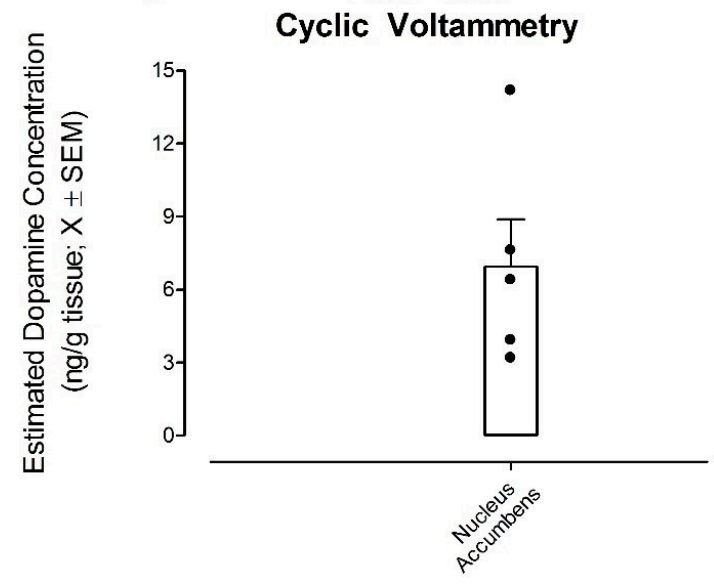

Figure 1. Graphical illustration of the profound differences in estimated dopamine (DA) concentration (ng/g of tissue; $\mathrm{X} \pm \mathrm{SEM}$ ) dependent upon methodology (i.e., (A) high-performance liquid chromatography, (B) microdialysis, (C) fast-scan cyclic voltammetry) and brain region. Each dot represents the estimated DA concentration from a study. 
Given HPLC's wide use, sources of random and systematic error in HPLC have been studied extensively [119]. The brief discussion in the present review will focus on sources of error reported to affect the electrochemical detection of DA. First, the mobile phase column composition (e.g., ion pairing agent type, organic modifier, $\mathrm{pH}$ ) has a pronounced effect on the capacity factor $\left(\mathrm{k}^{\prime}\right)$, retention time, peak height units of DA and peak symmetry [120-124]. Second, the flow gradient rate, similarly, has a prominent effect on the resolution of the eluting compounds, $\mathrm{k}^{\prime}$ and background current [125]. Finally, chromatographic instrumentation, including the column temperature, alters the retention time of DA, whereby an increase in column temperature is associated with a decrease in retention time [123]. Additionally, column age may influence the resolution between DA and its metabolite (i.e., 3,4-Dihydroxyphenylacetic acid), whereby decreased resolution has been observed after approximately 500 injections of the biological material directly onto the column top [121].

\subsection{Microdialysis}

The utilization of microdialysis to quantify neurotransmitters in the brain was first reported in the 1970s and 1980s [126-128], research which contributed significantly to the widespread implementation of microdialysis methods. Microdialysis relies on the principle of diffusion, whereby molecules move from an area of high concentration to an area of low concentration. Methodologically, a microdialysis probe composed of a semipermeable dialysis membrane is surgically implanted into the brain, and a perfusion medium is infused slowly and continuously [129]. During perfusion, molecules in the extracellular space diffuse through the semipermeable membrane, are transported into outflow tubing and are collected for analyte quantification (e.g., HPLC [129]; Figure 2A). Although microdialysis detects neurotransmitters at low- to sub-nanomolar levels (for DA, see [113]), the technique has relatively low spatiotemporal resolution and is unable to evaluate real-time changes in the neurochemical environment.

Despite being considered the "gold standard" for obtaining basal neurotransmitter levels, methodological limitations may impede precise and/or consistent measurements. The diameter of a typical microdialysis probe is approximately $300 \mu \mathrm{m}$, a size which is substantially larger than neurons and glial cells $(5-100 \mu \mathrm{m})$, as well as blood capillaries $(8-10 \mu \mathrm{m})$ and vessels $(\sim 1 \mathrm{~mm})$ in the brain [130]. Implantation of microdialysis probes, therefore, damages brain tissue, as evidenced by signs of ischemia [131,132] and a compromised blood-brain barrier [131,133]. Additionally, tissue damage resulting from the microdialysis probe disrupts synapses and neurons [134]. Critically, dopaminergic activity is disrupted by the implantation of microdialysis probes, as evidenced by both decreased DA release over post-probe implantation time [135] and alterations in the amplitude of evoked responses [136,137]. Recently developed novel approaches, including pharmacological agents [138,139] and a microfabricated probe [140], have the potential to mitigate some of the concerns regarding tissue disruption.

Consistent measurement of basal DA levels is further dependent upon multiple methodological details. Although HPLC is often used as a method to quantify the output from microdialysis, the methodological details discussed within the present section are conducted prior to the quantification of analytes. First, inappropriate concentrations of specific ions (e.g., $\mathrm{Ca}^{2+}, \mathrm{NA}^{+}, \mathrm{K}^{+}$) in the perfusate medium disrupt the homeostatic balance of the extracellular environment, altering the basal DA concentration. For example, increases in basal DA concentration are observed when the perfusate medium contains higher (e.g., $3.4 \mathrm{mM}$ ) levels of $\mathrm{Ca}^{2+}[63,141]$ or $\mathrm{K}^{+}$[128]. In sharp contrast, utilization of a perfusion solution with too little $\mathrm{Ca}^{2+}[128,142]$ or too little $\mathrm{K}^{+}[142]$ results in decreased extracellular DA levels. It is vital, therefore, that the composition of perfusion solutions mimic the brain extracellular fluid; additional parameters, including $\mathrm{pH}$ and temperature, are also critical considerations [143]. Second, substantial increases in the concentrations of extracellular DA occur immediately following death [144-146]. Basal DA levels subsequently decrease as the postmortem interval increases [144-146]; albeit, basal DA concentration remains 
elevated, relative to pre-death levels, for at least an hour postmortem [144,145]. Third, in neutral and basic aqueous solutions, DA degrades rapidly [147], including in many common (e.g., aCSF, brain dialysate) perfusion solutions [148]. Several approaches, including temporal proximity (i.e., minimization of the time between sample collection and analysis [149]), addition of stabilizing agents to either the collection bins [65] or microdialysis media [150] and a microdialysis/LCMS system [148], have been implemented to mitigate the DA instability problem. Despite the validity of these approaches, inter-laboratory differences may preclude determining an estimate of the "true" basal DA concentration.

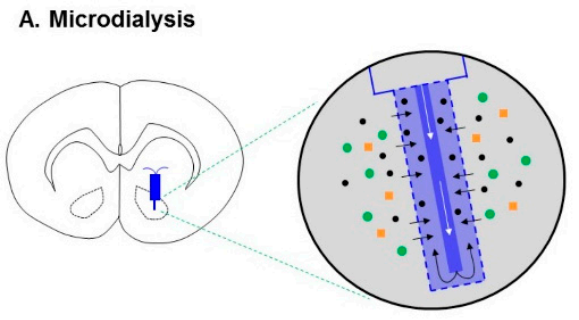

B. Fast Scan Cyclic Voltammetry

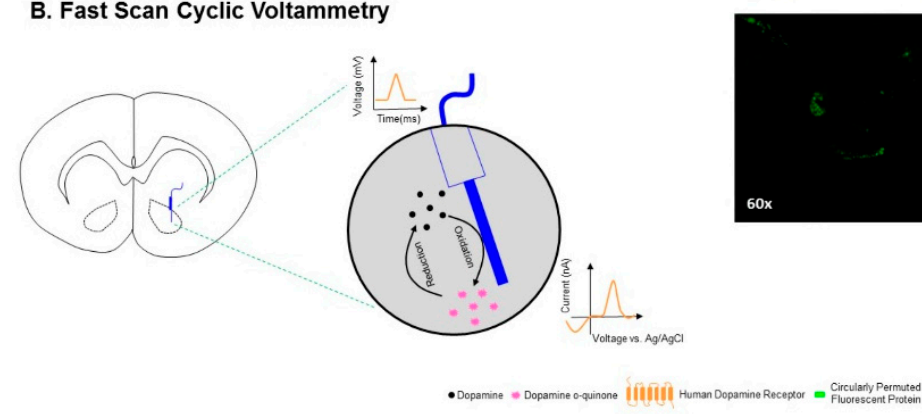

C. G-Protein Coupled Receptor Biosensors (e.g., GRAB ${ }_{D A}$ )

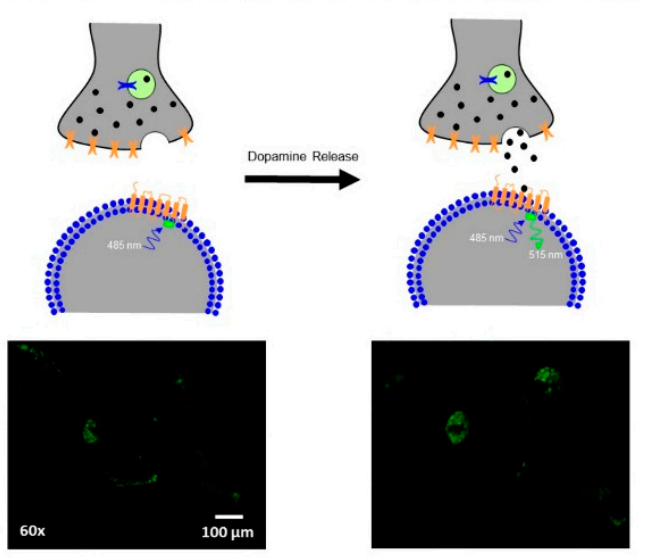

Figure 2. Technical illustration of three of the prominent methods utilized to detect dopamine (DA) levels in the CNS. Given that high-performance liquid chromatography (HPLC) is more classically used for analyte quantification on brain tissue homogenates or following microdialysis, the method is not illustrated. (A) During microdialysis, a probe composed of a semipermeable dialysis membrane is surgically implanted into the brain, and a perfusion medium (white arrows) is infused slowly and continuously. During perfusion, molecules in the extracellular space diffuse through the semipermeable membrane, and are transported into outflow tubing and collected for analyte quantification (e.g., HPLC). (B) In fast-scan cyclic voltammetry, a small carbon-fiber microelectrode is surgically implanted into the brain. The voltage potential at the carbon-fiber microelectrode is rapidly increased and decreased, resulting in the oxidation and reduction of DA. During the oxidation and reduction processes, the transfer of electrons is measured in current at the surface of the carbon-fiber microelectrode, and the amount of current can be subsequently converted into the concentration of DA. Additionally, the voltammogram is used for analyte identification, whereby DA exhibits one oxidation and one reduction peak. (C) More recently, G-protein coupled receptor (GPCR) biosensors for DA have been developed, affording an opportunity to track the release dynamics of DA. DA biosensors have a circularly permuted fluorescent protein (e.g., Green: cpGFP, Red: cpmApple) inserted into the third intracellular loop of the DA receptor. When DA binds to the endogenous ligand, the GPCR exhibits a conformational change, resulting in an increased fluorescent intensity. Our laboratory has recently transfected cells with GRAB-DA2m, a DA receptor 2 subtype biosensor, in vitro. Upon stimulation with $100 \mathrm{~nm}$ DA, an increase in the fluorescence intensity of cpGFP is observed.

\subsection{Fast-Scan Cyclic Voltammetry (FSCV)}

FSCV, an electroanalytical technique developed in the early 1980s [151,152], affords a method to detect rapid neurotransmitter dynamics in the brain [153]. From a theoretical perspective, FSCV relies upon chemical sensing of neurotransmitters at carbon-fiber microelectrodes. Specifically, the voltage potential at the carbon-fiber microelectrode is rapidly increased and decreased, resulting in the oxidation and reduction of electroactive substances [154]. Examination of the cyclic voltammogram, which presents data as time ( $x$-axis) by voltage (y-axis), allows for compound identification $[155,156]$. The strengths of FSCV include its high spatial (micrometer) acuity, high temporal (sub-second) resolution 
and high chemical (nanomolar range) sensitivity. However, FSCV is limited by the need for digital background subtraction [157], which restricts measurements to relative neurotransmitter changes, a factor which precludes the measurement of basal concentrations of electroactive species [154]. Therefore, FSCV has typically been utilized to measure phasic, rather than tonic, DA release. Recent novel modifications have afforded an opportunity to investigate tonic DA concentrations using FSCV [103,104,158,159]. While an in-depth discussion of these modifications is beyond the scope of this review, it is an emerging area of research that has the potential to transform our ability to accurately measure basal DA levels.

\subsection{G Protein-Coupled Receptor (GPCR) Biosensors}

GPCR biosensors for DA (or DA biosensors), the most recent method developed for monitoring DA dynamics, were first reported in 2018 [160,161], and contemporary versions have expanded upon these initial reports [162,163]. Theoretically, fluorescent DA biosensors rely upon the interaction between DA and $\mathrm{D}_{1}$ - and $\mathrm{D}_{2}$-like GPCRs. DA biosensors were developed by inserting a genetically encoded, circularly permuted fluorescent protein (e.g., Green: cpGFP, Red: cpmApple) into the third intracellular loop of the naturally occurring human DA receptor. When DA is released, it binds to the endogenous ligand, causing a rapid conformational change in the GPCR, a conformational change that induces a profound increase in fluorescence intensity (i.e., 90-900\%, for a review, see [164]; Figure 2C). DA biosensors exhibit high selectivity, molecular specificity, affinity (sub-micromolar) and resolution (sub-second [160-163,165]), making them ideally suited for tracking DA release. However, DA biosensors may be limited by low basal fluorescence levels, which precludes the detection of basal DA levels. A more comprehensive discussion of GPCR biosensors for DA is provided by Labouesse et al. [164].

\subsection{General Experimental Considerations}

Ideally, an estimate of basal DA values would be highly replicable when measurements are obtained in the same brain region, using the same methodological technique and in nearly genetically identical animals. However, basal DA concentrations are altered by natural biological variation within and between subjects. Independent of species, there is natural biological variation in basal DA concentrations resulting from within and between subject's factors. For example, basal extracellular DA levels change across the functional lifespan, with significantly decreased DA observed in aged, relative to young, animals [166]. Furthermore, basal DA levels in the NAc [167,168], striatum [149,169] and medial prefrontal cortex (mPFC [170]) fluctuate in a circadian rhythm. Additionally, hormones have a profound impact on basal DA levels, as evidenced by changes across the estrous cycle [171,172] and resulting from gonadectomy [173].

To date, the substantial variability between studies, even within a single methodological approach, has obfuscated our ability to experimentally determine the "true" basal DA concentration. When appropriate experimental controls are implemented, the impact of a treatment (e.g., HIV-1, substance use) on basal DA concentration can be reliably determined; comparing between studies, however, remains challenging. Stringent and detailed reporting of methodological procedures may aid in determining which studies can be most accurately compared. From a practical perspective, however, the information compiled in Table 1 (expanded in Supplementary Table S1) provides a summary of the techniques currently in use.

In sum, HPLC of tissue homogenates may reveal total DA tissue content, while microdialysis enables sampling of the extracellular basal DA levels, but lacks temporal resolution (minutes) and spatial resolution. FSCV is currently used for relative changes in DA signals, and not for assessing basal DA levels. Although GPCR biosensors for DA may not clarify basal DA levels in the brain, their ability to rapidly detect DA function has the potential to transform our understanding of neural circuits. Critically, each neurochemical 
method for assessing DA levels has benefits and limitations that must be weighed when designing an experiment.

\section{Chronic HIV-1 Results in Decreased Dopamine}

Inconsistencies in the estimated basal DA values does not preclude the utilization or importance of these methodological techniques for evaluating group differences. As demonstrated in Table 2, HPLC, microdialysis and FSCV have been fundamental in elucidating how HIV-1 viral protein exposure alters basal DA concentration relative to seronegative individuals or controls. Results (Table 2) overwhelmingly support decreased DA concentrations following chronic HIV-1 viral protein exposure in either HIV-1 seropositive humans or biological systems utilized to model HIV-1.

Despite the overwhelming support for a hypodopaminergic state in HIV-1 (i.e., low levels of DA), there are a few outliers. Three studies [174-176] have reported transitory increases in DA concentration in the CSF, caudate putamen and prefrontal cortex (PFC), respectively. The subjects (i.e., humans, mice) evaluated in these studies share a key commonality: early or acute HIV-1. Specifically, the clinical sample included individuals in clinical stage 1 [174], which is characterized by asymptomatic infection and persistent generalized lymphadenopathy [177]. Preclinical measurements were conducted either one [176] or three [175] days after the completion of Tat protein induction by a doxycycline regimen. Critically, these increases in DA either failed to persist for longer intervals after Tat protein induction (i.e., 10 Days: [178], 40 Days: [175]) or were brain regionspecific [176]. Moreover, there is no evidence for a hyperdopaminergic state during chronic HIV-1 infection in humans, suggesting little clinical relevance for assessing acute increases in dopamine.

Another notable inference that can be drawn from Table 2 regards the influence of cART on DA function in HIV-1 seropositive individuals. While monotherapy, including zidovudine (azidothymidine), was first implemented in 1985 [19], cART began in 1996. Critically, the strong support for decreased dopaminergic function spans across studies in both the pre- and post-cART era. A more comprehensive discussion for the potential role of cART in dopaminergic system dysfunction is presented in Section 5.

Undoubtedly, long-term HIV-1 viral protein exposure leads to persistent DA deficits, independent of treatment with cART. It is possible that there is an initial transient increase in DA immediately following HIV-1 infection, given the increased life expectancy for HIV-1 seropositive individuals $[179,180]$, however, the acute phase fails to accurately reflect the current clinical syndrome.

Table 2. Influence of HIV-1 viral protein exposure on dopamine (DA) concentration relative to controls. Asterisks $\left(^{*}\right)$ indicate manuscripts that measured DA metabolites (e.g., homovanillic acid). Symbols: DA concentration is decreased ( $)$ or increased ( ) relative to controls. The equal sign ( between HIV and controls.

\begin{tabular}{|c|c|c|c|c|c|}
\hline References & $\begin{array}{c}\text { DA Concentration } \\
\text { Relative to } \\
\text { Controls }\end{array}$ & Virus & Brain Region & Species & Method \\
\hline Larsson et al., 1991 [16] & & HIV & CSF & Human & HPLC * \\
\hline Berger et al., 1994 [14] & & HIV & CSF & Human & HPLC \\
\hline Sardar et al., 1996 [15] & & HIV & Caudate Nucleus & Human & HPLC \\
\hline
\end{tabular}


Table 2. Cont.

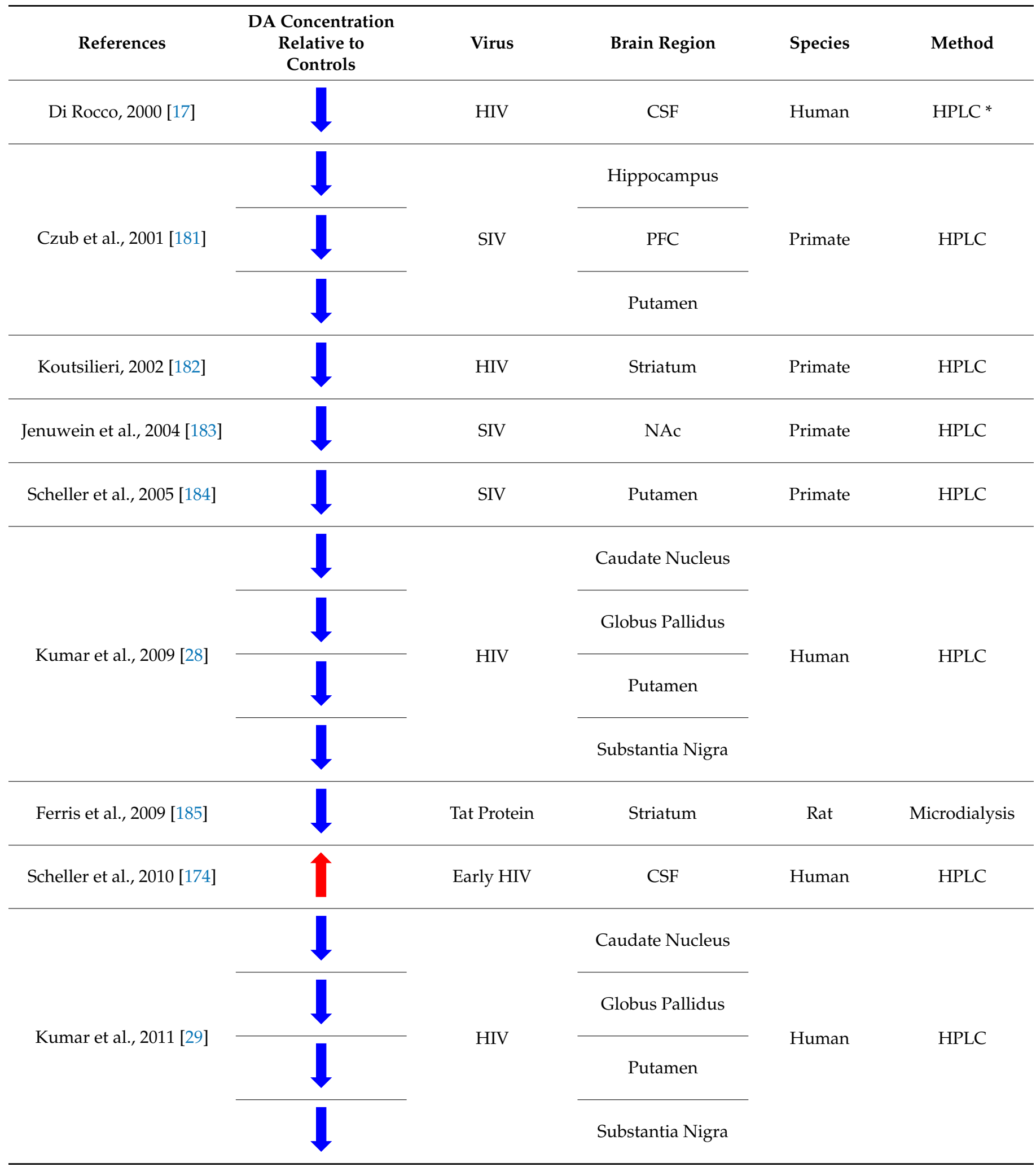


Table 2. Cont.

\begin{tabular}{|c|c|c|c|c|c|}
\hline References & $\begin{array}{l}\text { DA Concentration } \\
\text { Relative to } \\
\text { Controls }\end{array}$ & Virus & Brain Region & Species & Method \\
\hline \multirow{4}{*}{ Kesby et al., 2016 [175] } & & \multirow[t]{2}{*}{ Acute Tat Protein } & Caudate Putamen & \multirow[t]{2}{*}{ Mouse } & \multirow[t]{2}{*}{ HPLC } \\
\hline & & & NAc & & \\
\hline & & \multirow{2}{*}{ Tat Protein } & Caudate Putamen & \multirow{2}{*}{ Mouse } & \multirow{2}{*}{ HPLC } \\
\hline & & & NAc & & \\
\hline \multirow{4}{*}{ Kesby et al., 2016 [178] } & & \multirow{4}{*}{ Acute Tat Protein } & Caudate Putamen & \multirow{4}{*}{ Mouse } & \multirow{4}{*}{ HPLC } \\
\hline & & & Hippocampus & & \\
\hline & & & PFC & & \\
\hline & & & OFC & & \\
\hline Horn et al., 2017 [186] & & HIV & CSF & Human & HPLC \\
\hline $\begin{array}{l}\text { Javadi-Paydar et al., } \\
2017 \text { [187] }\end{array}$ & & HIV-1 Proteins & NAc & Rat & $\begin{array}{l}\text { Ex vivo slice } \\
\text { voltammetry }\end{array}$ \\
\hline Denton et al., 2019 [30] & & HIV-1 Proteins & NAc & Rat & FSCV \\
\hline Saloner et al., 2020 [188] & & HIV & CSF & Human & HPLC \\
\hline \multirow[t]{2}{*}{ Strauss et al., 2020 [176] } & & \multirow[t]{2}{*}{ Acute Tat Protein } & PFC & \multirow[t]{2}{*}{ Mouse } & \multirow[t]{2}{*}{ HPLC } \\
\hline & & & Striatum & & \\
\hline Denton et al., 2021 [189] & & HIV-1 Proteins & NAc & Rat & FSCV \\
\hline
\end{tabular}

\section{HIV-1 Clinical Symptoms Reflect a Hypodopaminergic State}

In 2007, the nosology for neurological complications in HIV-1 seropositive individuals was updated to reflect the milder phenotype of $\mathrm{NCI}$ and affective alterations, collectively termed HIV-1-associated neurocognitive disorders (HAND), observed in the post-cART era [190]. Using the established criteria, HIV-1 seropositive individuals are classified into one of three categories (i.e., asymptomatic neurocognitive impairment (ANI), mild neurocognitive disorders (MND) or HAD) based on neurocognitive performance and alterations in daily functioning [190]. HAND, a progressive disease [191-195], is characterized by prominent neurocognitive deficits in speed of information processing, attention, working memory and executive function $[26,196,197]$. Affective alterations commonly observed in HAND include apathy $[27,198]$ and depression $[199,200]$. These clinical symptoms reflect persistent DA deficits in HIV-1 seropositive individuals.

The present review will focus on evaluating the role of DA in the regulation of preattentive processes, attention and apathy, as a discussion of all neurocognitive and/or affective alterations, neural circuits and/or cellular mechanisms is beyond the scope. However, it is notable that the effect of decreased DA availability in HIV-1 seropositive individuals extends more broadly, as it is significantly associated with neuropsychological performance [29] and depression [188]. Furthermore, Figure 3 illustrates the profound difference in the clinical symptoms of hyperdopaminergic versus hypodopaminergic systems. 
There is no clinical evidence supportive of high dopamine levels following chronic HIV-1 infection in humans, suggesting that models/therapeutics must focus on rectifying low dopamine levels.

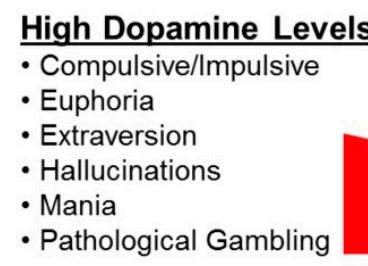

\section{Low Dopamine Levels}

- Anhedonia

- Apathy

- Depression

- Impaired Action Initiation

- Reduced Reward Seeking

- Cognitive Deficits

Figure 3. Overview of behaviors characteristic of a hyperdopaminergic versus hypodopaminergic state.

\subsection{Pre-Attentive Processes}

Pre-attentive processing (or sensorimotor gating) is defined as the screening of extraneous information to facilitate the uninterrupted processing of relevant information. Prepulse inhibition (PPI) of the auditory startle response (ASR), popularized by Hoffman and Ison [201,202], affords a translational experimental paradigm to measure pre-attentive processes. The presentation of a discrete pre-stimulus prior to a startling stimulus attenuates an individual's startle response during a brief temporal window (i.e., 30-500 msec [203]). Prominent impairments in PPI have been observed in multiple neuropsychological disorders, including schizophrenia [204], obsessive-compulsive disorder [205,206], Huntington's disease [207] and HIV-1 [208,209]. In HIV-1, deficits in PPI are characterized by a reduction in percent PPI $[208,210]$ and a relative insensitivity to the manipulation of interstimulus interval (ISI, i.e., time between the discrete pre-stimulus and startling stimulus $[209,211]$ ). Most critically, impairments in PPI resulting from chronic HIV-1 viral protein exposure are associated with alterations in higher-order cognitive processing [208], progress across the functional lifespan $[212,213]$ and may serve as a diagnostic and/or prognostic biomarker for HAND [214].

PPI is regulated, at least in part, by brain regions integral to the fronto-striatal circuit (i.e., ventral tegmental area (VTA), NAc and PFC) and the dopaminergic system. Specifically, within the neural circuit mediating PPI, the NAc is innervated by dopaminergic projections from the VTA and glutamatergic afferents from the mPFC. Gamma aminobutyric acid (GABA) projections are subsequently relayed from the NAc to the pedunculopontine tegmental nucleus (PPTg). Information is then sent from the PPTg to the caudal pontine reticular nucleus, a component of the acoustic startle circuit [215], resulting in the elicitation of a startle response. The auditory startle pathway and entire neural circuitry underlying PPI is more comprehensively reviewed by Koch [216] and Fendt et al. [217].

Profound reductions in PPI are observed when pharmacological manipulations and lesioning approaches are utilized to induce a hypodopaminergic state. Apomorphine, a direct dopamine agonist, acts in a biphasic dose-dependent manner [218,219], whereby low doses act on presynaptic receptors, resulting in decreased dopaminergic tone; high doses of apomorphine, in sharp contrast, act on both pre- and post-synaptic receptors, resulting in a hyperdopaminergic state. Administration of low doses of apomorphine, independent of sensory modality (i.e., auditory, visual [220]) or ISI [221], leads to prominent reductions in PPI [220-222]. Selective D1 receptor antagonists, including SCH23390 [223,224] and SCH39166 [225], also reduce PPI when injected into either the PFC $[223,225]$ or dorsal striatum [224]. Furthermore, inducing a hypodopaminergic tone via 6-hydroxydopamine (6-OHDA) injections, which destroys dopaminergic and noradrenergic neurons [226,227], reduces PPI [228,229]. Collectively, pre-attentive processes, as indexed by PPI, are dramatically reduced under conditions that mimic a hypodopaminergic state, reductions which are similar to those observed in HIV-1 in the post-cART era. 


\subsection{Attention}

Attention is a biologically complex cognitive function dependent upon reciprocal excitatory and inhibitory processes [230]. By definition, attention is selective, requiring the brain to process the most relevant information, while excluding, or inhibiting, irrelevant information [230]. According to a hierarchical model proposed by Sohlberg and Mateer [231,232], attention can be divided into multiple subcomponents (i.e., arousal, focused attention, sustained attention, selective attention, alternating attention and divided attention). With regards to HIV-1, chronic HIV-1 viral protein exposure induces prominent deficits across the subcomponents of attention, including sustained attention or vigilance [233], selective attention [234,235] and divided attention [236].

Although the precise neural circuitry underlying attentional processes has not yet been fully elucidated, there is strong evidence for the fundamental role of the PFC in higherorder cognition. The PFC is divided into six layers, superficial to deep, and is comprised of three major subdivisions, including the lateral PFC (IPFC), MPFC and orbital PFC (oPFC [230]). Midbrain DA neurons project to the PFC via the mesocortical DA pathway, a pathway which can be divided into two parallel systems [237]. Specifically, DA afferents from the VTA innervate the MPFC, whereas the IPFC is innervated by DA projections from the substantia nigra [237]. Most critically, however, DA modulates cognitive processes, including attention, in the PFC.

Induction of a hypodopaminergic state via pharmacological manipulations or lesioning approaches disrupts attentional behavior. First, local administration of the selective D1 antagonist SCH23390 to either the PFC $[238,239]$ or NAc [240] impairs attention. Infusion of the D2 receptor antagonist sulpiride into the NAc [240], but not the PFC [238], also decreased attentional accuracy. Second, neonatal treatment with 6-OHDA produces persistent marked impairments in selective, spatial and/or sustained attention at a juvenile stage [241,242], during adolescence [243] and in adulthood [244]. 6-OHDA lesions of the PFC during adulthood also reduced selective attention, as evidenced by an increased susceptibility to task-irrelevant distractors [245]; attentional set shift, however, is relatively spared [245,246], consistent with observations following chronic HIV-1 viral protein exposure [233]. Furthermore, chronic administration of the selective dopaminergic neurotoxin 1-methyl-4-phenyl-1,2,3,6-tetrahydropyridine (MPTP) induced attentional deficits, characterized by impairments in sustained spatial attention and focused attention [247]. Taken together, induction of a hypodopaminergic state produces marked impairments in attentional processes similar to those observed in HIV-1 in the post-cART era.

\subsection{Apathy}

Traditionally, apathy has been defined as a lack of motivation [248] that is evidenced by the quantitative reduction in voluntary and goal-directed behaviors [249]. Goal-directed behaviors require the use of action to translate an internal state into the attainment of a goal. In clinical studies, apathy is most commonly [250] assessed using either the Apathy Evaluation Scale [251] or the Neuropsychiatric Inventory [252], scales which exhibit both strong reliability and validity [250]. Furthermore, preclinical studies have utilized operant and Pavlovian conditioning as a method to evaluate how willing an animal is to "work" for reinforcement $[198,253,254]$. Understanding apathy from both a clinical and preclinical perspective is vital, given its prevalence in many neurological disorders (e.g., Alzheimer's disease [255], Parkinson's disease [256], HIV-1 [27,257]). Indeed, chronic HIV-1 viral protein exposure induces prominent alterations in goal-directed behaviors $[198,254]$. The clinical significance of apathy in HIV-1 seropositive individuals cannot be understated, as increased apathy is significantly associated with greater impairments in activities of daily living [27,258], decreased medication adherence [259] and decreased quality of life [260].

Apathy is regulated, at least in part, by the anterior cingulate circuit, one of the behaviorally relevant fronto-striatal circuits [261]. Within this circuit, projections from the anterior cingulate cortex innervate the ventral striatum, including the NAc [262]. Subsequently, neurons in the ventral striatum project to the globus pallidus interna, ventral pallidum and 
rostrodorsal substantia nigra [263]. Both the ventral striatum and anterior cingulate cortex receive dopaminergic innervation from the VTA, supporting the fundamental role of DA in apathetic behaviors.

Indeed, the reduction of dopaminergic signaling via lesioning and chemogenetic approaches have demonstrated the importance of the neurotransmitter in goal-directed behavior. Induction of hypodopaminergic tone via either 6-OHDA lesions of the substantia nigra pars compacta [264-266] or MPTP [267] impaired motivated behaviors. More recently, the chemogenetic inhibition of DA neurons in the VTA dose-dependently reduced effortbased motivation [268]. Collectively, strong evidence supports apathetic behaviors under hypodopaminergic states.

\section{Role of cART in Dopaminergic System Dysfunction}

Currently, approximately 30 antiviral drugs are approved for the treatment of HIV1 [269]. The approach to HIV-1 treatment evolved from the use of monotherapy with the nucleoside reverse transcriptase inhibitor (NRTI) zivodudine, to various combinations of two to four compounds composed of a NRTI, integrase strand inhibitor (INSTI), protease inhibitor (PI), or non-nucleoside reverse transcriptase inhibitors (NNRTI). Given that a hypodopaminergic tone is observed following chronic HIV-1 viral protein exposure, it is vital to examine the potential role of cART in dopaminergic dysregulation.

Some cART drugs, particularly those with greater CNS penetrance [270], are associated with adverse psychoactive effects in HIV-1 seropositive individuals [271-274]. Specifically, NRTIs, including efavirenz, are most commonly associated with adverse neuropsychiatric outcomes [275]. Patients commonly report hallucinations, delusion, paranoia and mania, as well as depression, anxiety, nervousness, dizziness, sleep disturbances and abnormal dreams [271-274].

Efavirenz exhibits a complex neuropharmacological profile, whereby it interacts with serotonin (5-HT) and $\mathrm{GABA}_{\mathrm{A}}$ receptors, and multiple monoamine transporters (i.e., serotonin transporter (SERT), dopamine transporter (DAT), vesicular monoamine transporter 2 (VMAT2) [276-278]). Further evidence for these interactions is provided by increased basal levels of 5-HT, DA, and norepinephrine, albeit in a region-specific manner, following intraperitoneal injections of $5 \mathrm{mg} / \mathrm{kg}$ of efavirenz every other day for two weeks [279]. Under differing experimental conditions, acute, oral administration of efavirenz $(0,25$, $50 \mathrm{mg} / \mathrm{kg}$ ) dose-dependently increased striatal DA levels; however, no significant alterations in basal DA levels were observed after sub-chronic (i.e., two-week) exposure [280]. Highly translational behavioral procedures examining a drug's pharmacodynamic activity (e.g., drug discrimination, sensitization/habituation) and DA-related behaviors (e.g., drug reinforcement, conditioned reward behaviors) support the observed neuropharmacological profile and will be discussed in turn below.

\subsection{Drug Discrimination}

Drug discrimination is a free-operant procedure that allows the animal to learn that a subjective drug effect (i.e., discriminative stimulus) sets the occasion for reinforcement of a particular response [281]. Specifically, following injection of a psychoactive drug, responses on one levers are reinforced. Whereas, following a saline, however, responses on the alternative lever are reinforced [282]. After the discrimination is learned, a novel drug can be injected to determine whether the training and test drug share discriminative stimulus properties. If the novel test drug produces a discriminative stimulus similar to the training drug, then animals will respond on the lever associated with the training drug; however, the rat will respond on the saline-associated lever if the novel drug discriminative stimulus is different than that of the training drug.

Using the drug discrimination procedure, Gatch et al. [276] examined whether efavirenz produced a discriminative stimulus similar to different drugs of abuse. First, a group of rats were trained to discriminate the subjective drug effect of lysergic acid diethylamine (LSD), a serotonin receptor agonist, from that produced by saline injection. When tested with 
various doses of efavirenz, rats responded as if LSD was onboard, an effect that is primarily mediated by the $5-\mathrm{HT}_{2 \mathrm{~A}}$ receptor. Results were confirmed by training a separate group of rats to discriminate an efavirenz-induced drug state from saline. Under testing conditions with LSD, animals responded on the lever associated with the training drug (i.e., efavirenz) rather than the saline-associated lever. Second, a separate group of rats were trained to discriminate the subjective drug effect of cocaine, a DA reuptake inhibitor, from saline. When rats were tested with various doses of efavirenz, they primarily responded on the saline-associated lever. Collectively, the pharmacodynamic activity of efavirenz resembles that of the 5-HT receptor agonist LSD.

\subsection{Sensitization}

Repeated exposure to psychoactive stimulants produces prominent behavioral changes (e.g., amphetamine [283], cocaine [284]). Specifically, following acute treatment with psychostimulants, laboratory animals exhibit hyperactivity. Repeated drug exposure, however, induces a progressive and persistent increase in hyperactive behavior, commonly termed "behavioral sensitization". Critically, the later stages of behavioral sensitization are accompanied by significant elevations in DA in response to a drug $[285,286]$. Measurement of locomotion following a drug challenge is the classic approach to evaluating behavioral sensitization.

With regards to efavirenz, there is no compelling evidence for behavioral sensitization. Rather, locomotor activity was suppressed in a dose-dependent $(3,10,30 \mathrm{mg} / \mathrm{kg}$, IP) manner following repeated administration. Critically, the time-course of the efavirenz-induced suppression for the highest dose $(30 \mathrm{mg} / \mathrm{kg})$ was nearly identical to that produced by LSD (3 mg/kg [276]). Furthermore, efavirenz increased head-twitching, a behavioral measure commonly utilized to profile serotonergic-like compounds; an increase that was abolished in $5-\mathrm{HT}_{2 \mathrm{~A}}$ receptor knockout mice [276]. More recently, oral efavirenz $(0,25,50 \mathrm{mg} / \mathrm{kg})$ failed to produce sensitization or suppression of line-crossings in an open-field test [280]. Similarly, Möller et al. [279] observed no statistically significant effect of efavirenz ( $5 \mathrm{mg} / \mathrm{kg}$ of efavirenz every other day for two weeks) on locomotor activity. Thus, the profile of efavirenz is again consistent with a serotonergic pharmacodynamic.

\subsection{Drug Self-Administration}

Preclinical drug self-administration procedures, which evaluate DA-related behaviors, became popularized in the 1960s with the advent of reliable, automated methods for intravenous (IV) drug self-administration [287,288]. The utility of preclinical drug self-administration procedures derives from both their face (i.e., animals self-administer addictive substances commonly abused by humans $[198,289,290])$ and predictive (i.e., successful identification of substance with high abuse liability; for review, see [291]) validity. Various routes of administration (e.g., oral [290], IV [198]) can be utilized in drug selfadministration experimental paradigms to accurately model drug self-administration in humans. For IV drug self-administration, rats are implanted with chronic indwelling jugular catheters and are trained to self-administer drugs by pressing a lever within operant conditioning chambers $[287,292]$. Similar to other reinforcers, dependence-producing drugs readily maintain behavior on various schedules of reinforcement.

To assess the reinforcing properties of efavirenz, animals were trained to self-administer the DA reuptake inhibitor, cocaine. Following stable self-administration behavior, IV cocaine was replaced with incrementally increasing doses of IV efavirenz (1.0, 0.32, 3.2, or $10.0 \mathrm{mg} / \mathrm{kg}$ per infusion). However, independent of dose, lever pressing dramatically decreased during tests in which IV efavirenz was the available reinforcer [276]. Thus, efavirenz fails to maintain operant (goal-directed) behavior [276], indicating that it lacks reinforcing properties associated with drugs that release DA throughout the fronto-striatal system [293]. 


\subsection{Conditioned Place Preference}

Conditioned place preference (CPP) is a Pavlovian learning procedure that evaluates the rewarding effect of a drug [294]. The CPP procedure repeatedly conditions an animal to two stimuli: a conditional stimulus (CS) and an unconditional stimulus (US). Specifically, one CS (e.g., dark environmental context) is paired with drug treatment (i.e., US). A second CS (e.g., bright environmental context) is paired with no drug treatment. Following conditioning, animals are tested, whereby the rodent can freely move between the drugpaired and non-drug-paired contexts. During testing, a CPP is learned if the animal spends relatively more time in the drug-paired context. Likewise, a conditioned place aversion (CPA) is learned if an animal spends an increased amount of time in the non-drug-paired context. Drugs that produce DA release and maintain self-administration also produce CPP (e.g., cocaine [295]); however, not all drugs that produce CPP are considered dopaminergic drugs [296]. Overall, the CPP experimental paradigm models a Pavlovian conditioning aspect of drug-taking behavior related to incentive salience conditioned to drug-associated stimuli [297].

Mixed findings fail to provide strong support for efavirenz-mediated conditioned reward learning [276,279]. Specifically, under one experimental condition, no dose of efavirenz tested (5-20 mg/kg, IP) produced CPP in rats [276]. On the other hand, dosedependent changes in behavior, ranging from CPP $(5 \mathrm{mg} / \mathrm{kg}$ of efavirenz) to CPA (20 mg/kg of efavirenz), were observed [279]. The CPP procedure is not considered an exclusive screen for dopaminergic drugs, as there are serotonin agonists (e.g., LSD, buspirone) that function as an US to produce CPP $[294,296,298]$. Thus, it is conceivable that the CPP observed by Moller et al. [279] was mediated by efavirenz's US effects on the serotonergic system [296,298].

\subsection{Conclusions}

Collectively, there is no compelling evidence that efavirenz binds to DA receptors (D1, D4 human; D2, D3 rat) or alters DA reuptake. Efavirenz does inhibit DA reuptake in human cloned DAT [276] and acutely increases basal DA levels $[279,280]$. However, highly translational behavioral procedures fail to support DA behaviors. Specifically, rats experience different interoceptive cue states when treated with systemic cocaine and efavirenz, as evidenced within a drug discrimination experimental paradigm. Furthermore, efavirenz fails to induce sensitization $[276,279,280]$ and is not self-administered by rats [276]. The hypodopaminergic tone observed following chronic HIV-1 viral protein exposure in both the pre- and post-cART eras (Table 2 above) adds additional credence to these observations. Efavirenz, however, resembles an LSD-like drug consistent with putative effects on the serotonergic system, effects which may produce adverse psychiatric alterations in HIV-1 seropositive individuals [276]. Thus, if cART contributes negatively to HAND, it is unlikely that it results from direct protein interactions to alter dopamine transmission via VMAT2, DAT, or DA receptors.

Whether efavirenz, or other cART-approved drugs, functionally alter DA release throughout fronto-striatal systems is a fundamental question. However, to date, few experiments have directly examined if and/or how cART drugs alter DA function. In addition to the reviewed studies examining efavirenz, the PIs ritonavir and saquinavir failed to alter DA release in rodent hypothalamic tissue [299]. Although the currently available data fail to support the impact of cART on DA, there remains a critical need for additional studies of individual and combinations of cART drugs.

\section{Mechanistic Implications for Low Dopamine Levels}

\subsection{Homeostatic Conditions}

Microglia, which represent $5-20 \%$ of adult brain cells [300], belong to the myeloid phagocytic/monocytic lineage [301,302] and serve as resident innate immune cells in the CNS. Morphologically, microglia are characterized by a small soma and slender, highly branched processes $[303,304]$. In the healthy brain, "resting" microglia utilize 
their branched processes to continuously survey the environment [303,304]; environmental surveillance which is uniquely targeted to synaptic structures [305,306]. Critically, strong evidence also supports a fundamental relationship between microglia and the dopaminergic system. Based on the available scientific evidence, which is reviewed in detail below, we propose a (potentially) cyclic model highlighting the interrelationships between microglia, the DA system and synaptic function (Figure 4).

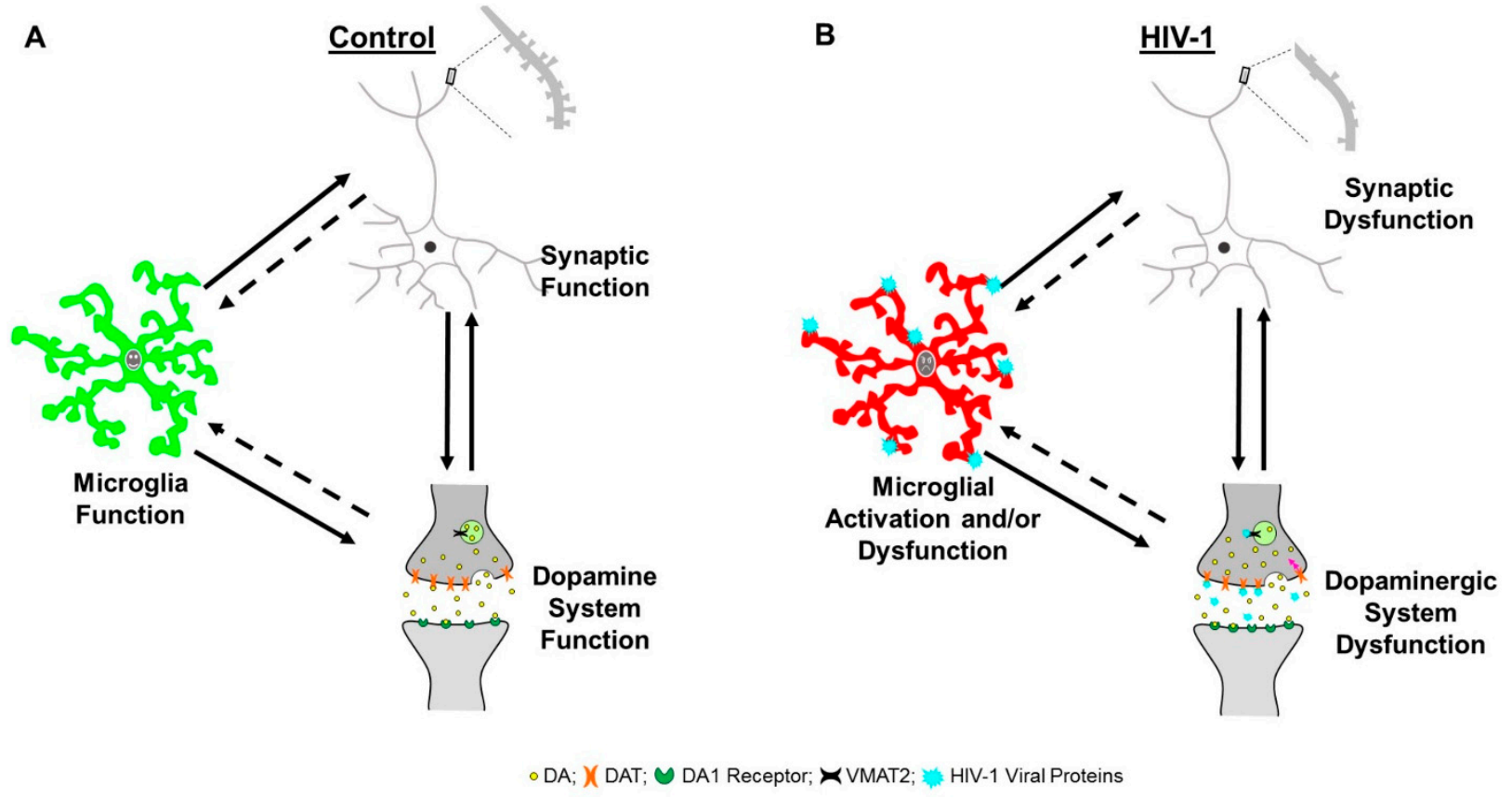

Figure 4. Proposed (potentially) cyclical model of the interrelationship between microglia, and synaptic and dopaminergic system function. (A) Under homeostatic conditions, microglia influence both the dopamine (DA) system and synaptic maintenance. Furthermore, synaptic and dopaminergic system functions exhibit a bidirectional relationship. To date, it is unknown whether the relationships between microglia and synaptic function or microglia and DA system function are bidirectional, as indicated via the dashed lines. (B) Chronic exposure to HIV-1 viral proteins induces activation, dysfunction and/or senescence of microglia, and microglial alterations which may underlie the prominent low DA levels and/or synaptic dysfunction observed in the post-cART era. DA: dopamine; DAT: dopamine transporter; DA1 Receptor: dopamine 1 receptor; VMAT2: vesicular monoamine transporter 2.

First, microglia and the DA system are highly interrelated, whereby microglia are highly prevalent in the basal ganglia nuclei (i.e., NAc, VTA, SN [307,308]) and express functional D1- and D2-like receptors [309-311], as well as DAT [312]. Functionally, prominent alterations in microglial morphology [312], enhanced microglial migration [309] and enhanced assembly of vimentin filaments [312] have been observed in "resting" microglia following DA treatment. Microglia are also involved in the wiring of the embryonic forebrain circuit, including dopaminergic axon outgrowth and positioning of neocortical interneurons, a process which is altered in cases of microglial dysfunction (i.e., via cell-depletion or genetic mutants [313]).

Second, microglia's environmental surveillance is uniquely targeted to synaptic structures, whereby "resting" microglial processes localize with both pre- and post-synaptic structures, including dendritic spines [305,306]. During early brain development, microglia are involved in either the phagocytic [314,315] or trogocytotic [316] elimination of synapses, playing a critical role in synaptic pruning, a regressive event that is vital for neural circuit refinement and maturation. However, absence of either the fractalkine receptor (Cx3cr1 [314,317]) or complement receptor 3 (CR3 [315]) precludes synaptic pruning and results in immature synaptic connectivity. Microglia's role in synaptic pruning 
continues through adolescence, whereby microglia transiently engulf dendritic spines in the PFC [318], and into adulthood [319].

In addition to synaptic pruning, microglia play a critical role in synaptic formation during development [316,317,320,321] and adult neurogenesis [322-324]. Specifically, microglia-dendrite interactions promote filopodia-like (i.e., immature postsynaptic protrusions that may develop into mature dendritic spines) formation [316,321]. Alterations in the gene expression of $\mathrm{C} \times 3 \mathrm{cr} 1$, which lead to a depletion of microglia, however, precluded spine formation [317]. Furthermore, microglia regulate adult neurogenesis via multiple mechanisms, including phagocytosis [322] and the phagocytosis secretome [324], as well as via a nucleotide-mediated mechanism (i.e., ADP receptors P2Y12 and P2Y13 [323,324]) and the TAM family tyrosine kinases [324].

Notably, the dopaminergic system and synaptic structures may also interact with one another in a bidirectional manner. Dopaminergic afferents predominantly establish synaptic contact on the dendritic spine neck [325], and postsynaptic D1 and D2 receptors are localized in perisynaptic sites, supporting the anatomical interrelationship between the DA system and dendritic spines [326]. DA depletion results in prominent structural alterations in medium spiny neurons (MSNs) of the NAc, including decreased dendritic spine density $[327,328]$ and decreased density of asymmetric synaptic contacts $[329,330]$. Additionally, a preferential loss of 'thin' spines, and a corresponding relative increase in 'stubby' spines, has also been reported in MSNs of the NAc following DA denervation [328]. Collectively, evidence supports a strong relationship between microglia, dopaminergic system function and synaptic function. To date, however, it is unknown whether the relationships between microglia and synaptic function or microglia and DA system function are bidirectional.

\subsection{Disturbances of Brain Homeostasis: HIV-1}

Early in the course of infection, HIV-1-infected monocytes migrate across the bloodbrain barrier, infiltrating the brain and infecting microglia [331,332]. During HIV-1 infection, increased expression of microglial markers (e.g., CD68, MHC II) in the brain has often been interpreted as microglial activation [333], and more recent evidence supports morphological changes associated with microglial activation (i.e., amoeboid [334]). Additionally, HIV-1 infection likely leads to microglial dysfunction, as evidenced by cellular senescence [335]. Given the strong interrelationships between microglia, the DA system and synaptic function, microglial dysfunction may underlie the hypodopaminergic state (reviewed in Section 3) and synaptic dysfunction [195,336,337] commonly observed following chronic HIV-1 viral protein exposure (Figure 4B).

First, alterations in the relationship between microglia and DA system function have been observed following induction of the HIV-1 viral protein, Tat [338]. Specifically, Tat simultaneously decreased the number of microglia (i.e., Iba1 immunoreactive cells) and the number of dopamine neurons (i.e., tyrosine hydroxylase positive neurons) in the substantia nigra pars compacta, while an impact of HIV-1 Tat induction was not observed in the VTA [338]. Second, microglial activation and/or dysfunction may underlie HIV1-associated synaptic dysfunction. HIV-1 viral proteins disrupt microglial proteins and receptors (e.g., Cx3cr1 [339], CR3 [340]) that underlie microglia-mediated neurite and preand post-synaptic engulfment [314,315,317]. Finally, chronic HIV-1 viral proteins may alter the bidirectional relationship between the dopaminergic system and synaptic structures. Specifically, in MSNs of the NAc, DA denervation induces a preferential loss of 'thin' spines, and a corresponding relative increase in 'stubby' spines [328], morphological changes which are consistent with the prominent shift towards 'stubby' spines reported following chronic HIV-1 viral protein exposure [337,341]. Thus, we posit that the activation and/or dysfunction of microglia underlies the prominent synaptic and dopaminergic system dysfunction observed in HIV in the post-cART era. Future studies directly investigating how these interrelationships are altered following chronic HIV-1 viral protein exposure 
have the potential to enhance our understanding of the neural mechanisms underlying HAND and identify novel targets for therapeutic development.

\section{Conclusions}

1. Dopamine values are dependent upon not only brain region, but also experimental approach (i.e., HPLC, microdialysis, or FSCV). Substantial variability in basal dopamine values may reflect differences in experimental parameters, and innovative genetic fluorescent probes may be a future direction for assessing dopamine signaling.

2. Results overwhelmingly support decreased dopamine concentrations following chronic HIV-1 viral protein exposure in either HIV-1 seropositive humans or biological systems utilized to model HIV-1. Therefore, future therapeutic approaches and models for the neurological complications of HIV-1 need to focus on rectifying decreased dopamine levels.

3. The clinical symptoms, including cognitive impairments and apathetic behaviors, reflect persistent dopamine deficits in HIV-1 seropositive individuals. There is no clinical evidence supporting increased dopamine following chronic HIV-1 infections.

4. To date, there is no compelling evidence that cART has any direct pharmacological action on the dopaminergic system-dopamine deficits persist in the current era of HIV-1 therapeutics.

5. HIV-1 infection likely leads to microglial dysfunction, which may have mechanistic implications for a chronic bidirectional interaction between low dopamine levels and synaptic dysfunction, implicated as neural mechanisms of HAND.

Supplementary Materials: The following are available online at https:/ /www.mdpi.com/article/10 .3390 /cells10082158/s1, Table S1: Basal Dopamine (DA) values reported by individual manuscript.

Author Contributions: K.A.M., M.H. and V.M. contributed equally to the review. All authors contributed to the manuscript and have read and agreed to the published version of the manuscript.

Funding: This work was supported in part by National Institutes of Health (NIH) grants HD043680, MH106392, DA013137 and NS100624.

Institutional Review Board Statement: Not applicable.

Informed Consent Statement: Not applicable.

Data Availability Statement: All relevant data are within the manuscript.

Acknowledgments: We are indebted to all lab members and colleagues who, over the years, have contributed with their work in the field of dopamine research to shape the HIV-1 model presented. We are particularly grateful to Adarsh Kumar, who pioneered the field of dopamine and HAND, and was an inspiration to all. Additionally, we would like to acknowledge the contributions of Hailong $\mathrm{Li}$ for establishing the $\mathrm{GRAB}_{\mathrm{DA}}$ sensors in our laboratory.

Conflicts of Interest: The authors declare no conflict of interest. The funders had no role in the design of the study; in the collection, analyses, or interpretation of data; in the writing of the manuscript, or in the decision to publish the results.

\section{References}

1. Snider, W.D.; Simpson, D.M. Neurological complications of acquired immune deficiency syndrome: Analysis of 50 patients. Ann. Neurol. 1983, 14, 403-418. [CrossRef] [PubMed]

2. Belman, A.L.; Ultmann, M.H. Neurological complications in infants and children with acquired immune deficiency syndrome. Ann. Neurol. 1985, 18, 560-566. [CrossRef]

3. Navia, B.A.; Jordan, B.D. The AIDS dementia complex: I. Clinical features. Ann. Neurol. 1986, 19, 517-524. [CrossRef] [PubMed]

4. Barré-Sinoussi, F.; Chermann, J.C. Isolation of a T-lymphotropic retrovirus from a patient at risk for acquired immune deficiency syndrome (AIDS). Science 1983, 220, 868-871. [CrossRef] [PubMed]

5. Gallo, R.C.; Salahuddin, S.Z. Frequent detection and isolation of cytopathic retroviruses (HTLV-III) from patients with AIDS and at risk for AIDS. Science 1984, 224, 500-503. [CrossRef]

6. Resnick, L.; Berger, J.R. Early penetration of the blood-brain-barrier by HIV. Neurology 1988, 38. [CrossRef] 
7. Shaw, G.M.; Harper, M.E. HTLV-III infection in brains of children and adults with AIDS encephalopathy. Science 1985, 227, 177-182. [CrossRef]

8. Ho, D.D.; Rota, T.R. Isolation of HTLV-III from cerebrospinal fluid and neural tissues of patients with neurologic syndromes related to the acquired immunodeficiency syndrome. N. Engl. J. Med. 1985, 313, 1493-1497. [CrossRef]

9. Levy, J.A.; Shimabukuro, J. Isolations of AIDS-associated retroviruses from cerebrospinal fluid and brain of patients with neurological symptoms. Lancet 1985, 2, 586-588. [CrossRef]

10. Navia, B.A.; Price, R.W. The acquired immunodeficiency syndrome dementia complex as the presenting or sole manifestation of human immunodeficiency virus infection. Arch. Neurol. 1987, 44, 65-69. [CrossRef] [PubMed]

11. Tross, S.; Price, R.W. Neuropsychological characterization of the AIDS dementia complex: A preliminary report. AIDS 1988, 2, 81-88. [CrossRef]

12. Navia, B.A.; Cho, E.S. The AIDS dementia complex: II. Neuropathology. Ann. Neurol. 1986, 19, 525-535. [CrossRef] [PubMed]

13. Kieburtz, K.D.; Epstein, L.G. Excitotoxicity and dopaminergic dysfunction in the acquired immunodeficiency syndrome dementia complex. Therapeutic implications. Arch. Neurol. 1991, 48, 1281-1284. [CrossRef] [PubMed]

14. Berger, J.R.; Kumar, M. Cerebrospinal fluid dopamine in HIV-1 infection. AIDS 1994, 8, 67-71. [CrossRef]

15. Sardar, A.M.; Czudek, C. Dopamine deficits in the brain: The neurochemical basis of parkinsonian symptoms in AIDS. Neuroreport 1996, 7, 910-912. [CrossRef]

16. Larsson, M.; Hagberg, L. Cerebrospinal fluid catecholamine metabolites in HIV-infected patients. J. Neursci. Res. 1991, 28 , 406-409. [CrossRef] [PubMed]

17. Di Rocco, A.; Bottiglieri, T. Decreased homovanilic acid in cerebrospinal fluid correlates with impaired neuropsychologic function in HIV-1-infected patients. Clin. Neuropharmacol. 2000, 23, 190-194. [CrossRef]

18. Silvers, J.M.; Aksenov, M.Y. Dopaminergic marker proteins in the substantia nigra of human immunodeficiency virus type 1-infected brains. J. Neurovirol. 2006, 12, 140-145. [CrossRef] [PubMed]

19. Mitsuya, H.; Weinhold, K.J. 3'-Azido-3'-deoxythymidine (BW A509U): An antiviral agent that inhibits the infectivity and cytopathic effect of human T-lymphotropic virus type III/lymphadenopathy-associated virus in vitro. Proc. Natl. Acad. Sci. USA 1985, 82, 7096-7100. [CrossRef]

20. Schmitt, F.A.; Bigley, J.W. Neuropsychological outcome of zidovudine (AZT) treatment of patients with AIDS and AIDS-related complex. N. Engl. J. Med. 1988, 319, 1573-1578. [CrossRef]

21. Portegies, P.; de Gans, J. Declining incidence of AIDS dementia complex after introduction of zidovudine treatment. BMJ 1989, 299, 819-821. [CrossRef]

22. Sidtis, J.J.; Gatsonis, C. Zidovudine treatment of the AIDS dementia complex: Results of a placebo-controlled trial. AIDS Clinical Trials Group. Ann. Neurol. 1993, 33, 343-349. [CrossRef]

23. Saylor, D.; Dickiens, A.M. HIV-associated neurocognitive disorder-pathogenesis and prospects for treatment. Nat. Rev. Neurol. 2016, 12, 234-248. [CrossRef] [PubMed]

24. Letendre, S.L.; Ellis, R.J. Neurologic complications of HIV disease and their treatment. Top HIV Med. 2010, 18, 45-55.

25. McArthur, J.C.; Steiner, J. Human immunodeficiency virus-associated neurocognitive disorders: Mind the gap. Ann. Neurol. 2010, 67, 699-714. [PubMed]

26. Heaton, R.K.; Franklin, D.R. HIV-associated neurocognitive disorders before and during the era of combination antiretroviral therapy: Differences in rates, nature, and predictors. J. Neurovirol. 2011, 17, 3-16. [CrossRef]

27. Kamat, R.; Woods, S.P. Implications of apathy for everyday functioning outcomes in persons living with HIV infection. Arch. Clin. Neuropsychol. 2012, 27, 520-531. [CrossRef] [PubMed]

28. Kumar, A.M.; Fernandez, J.B. Human immunodeficiency virus type 1 in the central nervous system leads to decreased dopamine in different regions of postmortem human brains. J. Neurovirol. 2009, 15, 257-274. [CrossRef]

29. Kumar, A.M.; Ownby, R.L. Human immunodeficiency virus infection in the CNS and decreased dopamine availability: Relationship with neuropsychological performance. J. Neurovirol. 2011, 17, 26-40. [CrossRef] [PubMed]

30. Denton, A.R.; Samaranayake, S.A. Selective monoaminergic and histaminergic circuit dysregulation following long-term HIV-1 protein exposure. J. Neurovirol. 2019, 25, 540-550. [CrossRef] [PubMed]

31. Global HIV \& AIDS Statistics-Fact Sheet. Available online: https://www.unaids.org/en/resources/fact-sheet (accessed on 4 July 2021).

32. Blaschko, H. Metabolism and storage of biogenic amines. Experientia 1957, 13, 9-12. [CrossRef] [PubMed]

33. Montagu, K.A. Catechol compounds in rat tissues and in brains of different animals. Nature 1957, 180, 244-245. [CrossRef]

34. Carlsson, A.; Lindqvist, M. On the presence of 3-hydroxytyramine in brain. Science 1958, 127, 471. [CrossRef]

35. Bertler, A.; Rosengren, E. Occurrence and distribution of dopamine in brain and other tisuses. Experientia 1959, $15,10-11$. [CrossRef]

36. Marsden, C. Dopamine: The rewarding years. Br. J. Pharmacol. 2006, 147, S136-S144. [CrossRef]

37. Egenrieder, L.; Mitricheva, E. No basal or drug-induced sex differences in striatal dopaminergic levels: A cluster and meta-analysis of rat microdialysis studies. J. Neurochem. 2020, 152, 482-492. [CrossRef]

38. Liu, C.; Goel, P. Spatial and temporal scales of dopamine transmission. Nat. Rev. Neurosci. 2021, 22, 345-358. [CrossRef]

39. Elchisak, M.A.; Cosgrove, S.E. Distribution of free and conjugated dopamine in monkey brain, peripheral tissues and cerebrospinal fluid determined by high-performance liquid chromatography. Brain Res. 1983, 279, 171-176. [CrossRef] 
40. Bradbury, A.J.; Costall, B. Laterality of dopamine function and neuroleptic action in the amygdala in the rat. Neuropharmacology 1985, 24, 1163-1170. [CrossRef]

41. Ebinger, G.; Bruyland, M. Distribution of biogenic amines and their catabolites in brains from patients with Alzheimer's disease. J. Neurol. Sci. 1987, 77, 267-283. [CrossRef]

42. Carvalho, M.C.; Albrechet-Souza, L. Changes in biogenic amine content of the prefrontal cortex, amygdala, dorsal hippocampus, and nucleus accumbens of rats submitted to single and repeated sessions of the elevated plus-maze test. Braz. J. Med. Biol. Res. 2005, 38, 1857-1866. [CrossRef]

43. Fadok, J.P.; Darvas, M. Long-term memory for pavlovian fear conditioning requires dopamine in the nucleus accumbens and basolateral amygdala. PLOS ONE. 2010, 5, e12751. [CrossRef]

44. Inglis, F.M.; Moghaddam, B. Dopaminergic innervation of the amygdala is highly responsive to stress. J. Neurochem. 1999, 72, 1088-1094. [CrossRef]

45. Weiss, F.; Maldonado-Vlaar, C.S. Control of cocaine-seeking behavior by drug-associated stimuli in rats: Effects on recovery of extinguished operant-responding and extracellular dopamine levels in amygdala and nucleus accumbens. Proc. Natl. Acad. Sci. USA 2000, 97, 4321-4326. [CrossRef] [PubMed]

46. Tor-Agbidye, J.; Yamamoto, B. Seizure activity and hyperthermia potentiate the increases in dopamine and serotonin extracellular levels in the amygdala during exposure to d-amphetamine. Toxicol. Sci. 2001, 60, 103-111. [CrossRef] [PubMed]

47. Adachi, S.; Endo, Y. Increased levels of extracellular dopamine in the nucleus accumbens and amygdala of rats by ingeting a low concentration of a long-chain Fatty Acity. Biosci. Biotechnol. Biochem. 2013, 77, 2175-2180. [CrossRef]

48. Juorio, A.V.; Chedrese, P.J. The concentration of dopamine and related monoamines in arteries and some other tissues of the sheep. Comp. Biochem. Phsyiol. C Comp. Pharmacol. Toxicol. 1990, 95, 35-37. [CrossRef]

49. Davis, D.G.; Sparks, D.L. Dopaminergic and serotonergic neurotransmitters in bone marrow transplant patients. J. Neurol. Sci. 1995, 130, 95-103. [CrossRef]

50. Wilson, J.M.; Levey, A.I. Differential changes in neurochemical markers of striatal dopamine nerve terminals in idiopathic Parkinson's disease. Neurology 1996, 47, 718-726. [CrossRef]

51. Mushoff, F.; Schmidt, P. Determination of dopamine and dopamine-derived (R)-/(S)-salsolinol and norsalsolinol in various human brain areas using solid-phase extraction and gas chromatography/mass spectrometry. Forensic Sci. Int. 2000, 113, 359-366. [CrossRef]

52. Elsworth, J.D.; Jentsch, J.D. Cozapine normalizes prefrontal cortex dopamine transmission in monkeys subchronically expoed to phencyclidine. Neuropsychopharmacology 2008, 33, 491-496. [CrossRef] [PubMed]

53. Rajput, A.H.; Sitte, H.H. Globus pallidus dopamine and Parkinson motor subtypes: Clinical and brain biochemical correlation. Neurology 2008, 70, 1403-1410. [CrossRef]

54. Goldstein, D.S.; Sullivan, P. Catechols in post-mortem brain of patients with Parkinson disease. Eur. J. Neurol. 2011, 18, 703-710. [CrossRef]

55. Robinson, T.E.; Camp, D.M. Does amphetamine preferentially increase the extracellular concentration of dopamine in the mesolimbic system of freely moving rats? Neuropsychopharmacology 1990, 3, 163-173.

56. Bosse, K.E.; Mathews, T.A. Ethanol-induced increases in extracellular dopamine are blunted in brain-derived neurotrophic factor heterozygous mice. Neurosci. Lett. 2011, 489, 172-176. [CrossRef] [PubMed]

57. Lucas, L.A.C.; McMillen, B.A. Differences in brain area concentrations of dopamine and serotonin in Myers' High Ethanol Preferring (mHEP) and outbred rats. J. Neural Transm. 2002, 109, 279-292. [CrossRef] [PubMed]

58. Wisman, L.A.B.; Sahin, G. Functional convergence of dopaminergic and cholinergic input is critical for hippocampus-dependent working memory. J. Neurosci. 2008, 28, 7797-7807. [CrossRef]

59. Bromek, E.; Haduch, A. Cytochrome P450 mediates dopamine formation in the brain in vivo. J. Neurochem. 2011, 118, 806-815. [CrossRef] [PubMed]

60. Choi, D.L.; Davis, J.F. Orexin signaling in the paraventricular thalamic nucleus modulates mesolimbic dopamine and hedonic feeding in the rat. Neuroscience 2012, 210, 243-248. [CrossRef] [PubMed]

61. Hu, L.; Yang, J. A new stress model, a scream sound, alters learning and monoamine levels in rat brain. Physiol. Behav. 2014, 123, 105-113. [CrossRef]

62. Rysz, M.; Bromek, E. Damage to the brain serotonergic system increases the expression of liver cytochrome P450. Drug Metab. Dispos. 2015, 43, 1345-1352. [CrossRef]

63. Moghaddam, B.; Bunney, B.S. Ionic composition of microdialysis perfusion solution alters the pharmacological responsiveness and basal outflow of striatal dopamine. J. Neurochem. 1989, 53, 652-654. [CrossRef]

64. Maisonneuve, I.M.; Keller, R.W. Interactions between ibogaine, a potential anti-addictive agent, and morphine: An in vivo microdialysis study. Eur. J. Pharmacol. 1991, 199, 35-42. [CrossRef]

65. Shoblock, J.R.; Sullivan, E.B. Neurochemical and behavioral differences between d-methamphetamine and d-amphetamine in rats. Psychopharmacology 2003, 165, 359-369. [CrossRef]

66. Salvatore, M.F.; Pruett, B.S. Comprehensive profiling of dopamine regulation in substantia nigra and ventral tegmental area. J. Vis. Exp. 2012, 66, e4171. [CrossRef] [PubMed]

67. Winner, B.M.; Zhang, H. Metabolism of dopamine in nucleus accumbens astrocytes is preserved in aged mice exposed to MPTP. Front. Aging Neurosci. 2017, 9, 410. [CrossRef] 
68. Bergamini, G.; Mechtersheimer, J. Chronic social stress induces peripheral and central immune activation, blunted mesolimbic dopamine function, and reduced reward-directed behaviour in mice. Neurobiol. Stress 2018, 8, 42-56. [CrossRef]

69. Hernandez, L.; Hoebel, B.G. Food reward and cocaine increase extracellular dopamine in the nucleus accumbens as measured by microdialysis. Life Sci. 1988, 42, 1705-1712. [CrossRef]

70. Pettit, H.O.; Pan, H.T. Extracellular concentrations of cocaine and dopamine are enhanced during chronic cocaine administration. J. Neurochem. 1990, 55, 798-804. [CrossRef] [PubMed]

71. Pothos, E.; Rada, P. Dopamine microdialysis in the nucleus accumbens during acute and chronic morphine, naloxone-precipitated withdrawal and clonidine treatment. Brain Res. 1991, 566, 348-350. [CrossRef]

72. Parsons, L.H.; Justice, J.B. Extracellular concentration and in vivo recovery of dopamine in the nucleus accumbens using microdialysis. J. Neurochem. 1992, 58, 212-218. [CrossRef]

73. Maisonneuve, I.M.; Glick, S.D. Interactions between ibogaine and cocaine in rats: In vivo microdialysis and motor behavior. Eur. J. Pharmacol. 1992, 212, 263-266. [CrossRef]

74. Chapman, M.A.; See, R.E. Neurotensin increases extracellular striatal dopamine levels in vivo. Neuropeptides 1992, 22, 175-183 [CrossRef]

75. Chen, J.; Marmur, R. Ventral tegmental microinjection of delta 9-tetrahydrocannabinol enhances ventral tegmental somatodendritic dopamine levels but not forebrain dopamine levels: Evidence for local neural action by marijuana's psychoactive ingredient. Brain Res. 1993, 621, 65-70. [CrossRef]

76. Blanchard, B.A.; Steindorf, S. Sex differences in ethanol-induced dopamine release in nucleus accumbens and in ethanol consumption in rats. Alcohol. Clin. Exp. Res. 1993, 17, 968-973. [CrossRef] [PubMed]

77. Anagnostakis, Y.; Spyraki, C. Effect of morphine applied by intrapallidal microdialysis on the release of dopamine in the nucleus accumbens. Brain Res. Bull. 1994, 34, 275-282. [CrossRef]

78. Hemby, S.E.; Martin, T.J. The effects of intravenous heroin administration on extracellular nucleus accumbens dopamine concentrations as determined by in vivo microdialysis. J. Pharmacol. Exp. Ther. 1995, 273, 591-598. [PubMed]

79. Blanchard, B.A.; Glick, S.D. Sex differences in mesolimbic dopamine responses to ethanol and relationship to ethanol intake in rats. Recent Dev. Alcohol. 1995, 12, 231-241. [PubMed]

80. Campbell, A.D.; McBride, W.J. Serotonin-3 receptor and ethanol-stimulated dopamine release in the nucleus accumbens. Pharmacol. Biochem. Behav. 1995, 51, 835-842. [CrossRef]

81. Weiss, F.; Parsons, L.H. Ethanol self-administration restores withdrawal-associated deficiencies in accumbal dopamine and 5-hydroxytryptamine release in dependent rats. J. Neurosci. 1996, 16, 3474-3485. [CrossRef]

82. Pearl, S.M.; Maisonneuve, I.M. Prior morphine exposure enhances ibogaine antagonism of morphine-induced dopamine release in rats. Neuropharmacology 1996, 35, 1779-1784. [CrossRef]

83. Kohl, R.R.; Katner, J.S. Ethanol and negative feedback regulation of mesolimbic dopamine release in rats. Psychopharmacology 1998, 139, 79-85. [CrossRef]

84. Yan, Q.S. Extracellular dopamine and serotonin after ethanol monitored with 5-minute microdialysis. Alcohol 1999, 19, 1-7. [CrossRef]

85. Maisonneuve, I.M.; Glick, S.D. Attenuation of the reinforcing efficacy of morphine by 18-methoxycoronaridine. Eur. J. Pharmacol. 1999, 383, 15-21. [CrossRef]

86. Yim, H.J.; Gonzales, R.A. Ethanol-induced increases in dopamine extracellular concentration in rat nucleus accumbens are accounted for by increased release and not uptake inhibition. Alcohol 2000, 22, 107-115. [CrossRef]

87. Szumlinski, K.K.; McCafferty, C.A. Interactions between 18-methoxycoronaridine (18-MC) and cocaine: Dissociation of behavioural and neurochemical sensitization. Brain Res. 2000, 871, 245-248. [CrossRef]

88. Szumlinski, K.K.; Maisonneuve, I.M. The potential anti-addictive agent, 18-methoxycoronaridine, blocks the sensitized locomotor and dopamine responses produced by repeated morphine treatment. Brain Res. 2000, 864, 13-23. [CrossRef]

89. Johnson, D.W.; Eodice, P. Decreased accumbens dopamine release after cocaine challenge in behaviorally sensitized female rats. Pharmacol. Biochem. Behav. 2000, 65, 659-664. [CrossRef]

90. Fadda, P.; Scherma, M. Baclofen antagonizes nicotine-, cocaine-, and morphine-induced dopamine release in the nucleus accumbens of rat. Synapse 2003, 50. [CrossRef] [PubMed]

91. Steinmiller, C.L.; Maisonneuve, I.M. Effects of dextromethorphan on dopamine release in the nucleus accumbnes: Interactions with morphine. Pharmacol. Biochem. Behav. 2003, 74, 803-810. [CrossRef]

92. Kosten, T.A.; Zhang, X.Y. Chronic neonatal isolation stress enhances cocaine-induced increases in ventral striatal dopamine levels in rat pups. Brain Res. Dev. Brain Res. 2003, 141, 109-116. [CrossRef]

93. Smith, J.E.; Co, C. Self-administered heroin and cocaine combinations in the rat: Additive reinforcing effects-supra-additive effects on nucleus accumbens extracellular dopamine. Neuropsychopharmacology 2006, 31, 139-150. [CrossRef] [PubMed]

94. Geiger, B.M.; Haburcak, M. Deficits of mesolimbic dopamine neurotransmission in rat dietary obesity. Neuroscience 2009, 159, 1193-1199. [CrossRef] [PubMed]

95. Borgkvist, A.; Malmlöf, T. Dopamine in the hippocampus is cleared by the norepinephrine transporter. Int. J. Neuropsychopharmacol. 2012, 15, 531-540. [CrossRef] [PubMed]

96. McCallum, S.E.; Cowe, M.A. $\alpha 3 \beta 4$ nicotinic acetylcholine receptors in the medial habenula modulate the mesolimbic dopaminergic response to acute nicotine in vivo. Neuropharmacology 2012, 63, 434-440. [CrossRef] 
97. Grotewold, S.K.; Wall, V.L. Effects of cocaine combined with a social cue on conditioned place preference and nucleus accumbens monoamines after isolation rearing in rats. Psychopharmacology 2014, 231, 3041-3053. [CrossRef]

98. Cummings, J.A.; Jagannathan, L. Sex differences in the effects of estradiol in the nucleus accumbens and striatum on the response to cocaine: Neurochemistry and behavior. Drug Alcohol Depend. 2014, 135, 22-28. [CrossRef]

99. Eggan, B.L.; McCallum, S.E. 18-Methoxycoronaridine acts in the medial habenula to attenuate behavioral and neurochemical sensitization to nicotine. Behav. Brain Res. 2016, 307, 186-193. [CrossRef] [PubMed]

100. Roitman, M.F.; Wheeler, R.A. Real-time chemical responses in the nucleus accumbens differentiate rewarding and aversive stimuli. Nat. Neurosci. 2008, 11, 1376-1377. [CrossRef]

101. Owesson-White, C.A.; Roitman, M.F. Sources contributing to the average extracellular concentration of dopamine in the nucleus accumbens. J. Neurochem. 2012, 121, 252-262. [CrossRef]

102. Dreyer, J.K.; Vander Weele, C.M. Functionally distinct dopamine signals in nucleus accumbens core and shell in the freely moving rat. J. Neurosci. 2016, 36, 98-112. [CrossRef]

103. Atcherley, C.W.; Wood, K.M. The coaction of tonic and phasic dopamine dynamics. Chem. Commun. 2015, 51, 2235-2238. [CrossRef]

104. Johnson, J.A.; Rodeberg, N.T. Measurement of basal neurotransmitter levels using convolution-based nonfaradaic current removal. Anal. Chem. 2018, 90, 7181-7189. [CrossRef] [PubMed]

105. Kita, T.; Matsunari, Y. Methamphetamine-induced striatal dopamine release, behavior changes and neurotoxicity in BALB/c mice. Int. J. Dev. Neurosci. 2000, 18, 521-530. [CrossRef]

106. Bałkowiec-Iskra, E.; Kurkowska-Jastrzebska, I. MPTP-induced central dopamine depletion exacerbates experimental autoimmune encephalomyelitis (EAE) in C57BL mice. Inflamm. Res. 2007, 56, 311-317. [CrossRef]

107. Petzinger, G.M.; Walsh, J.P. Effects of treadmill exercise on dopaminergic transmission in the 1-methyl-4-phenyl-1,2,3,6tetrahydropyridine-lesioned mouse model of basal ganglia injury. J. Neurosci. 2007, 27, 5291-5300. [CrossRef] [PubMed]

108. Swiercz, R.; Grzelińska, Z. Catecholamine levels in the brain of rats exposed by inhalation to benzalkonium chloride. Int. J. Occup. Med. Environ. Health 2009, 22, 107-113. [CrossRef]

109. Villar-Cheda, B.; Dominguez-Meijide, A. Aging-related dysregulation of dopamine and angiotensin receptor interaction. Neurobiol. Aging 2014, 35, 1726-1738. [CrossRef] [PubMed]

110. Nikishina, Y.O.; Sapronova, A.Y. The effect of dopamine secreted by the brain into the systemic circulation on prolactin synthesis by the pituitary gland in ontogenesis. Acta Naturae 2016, 8, 111-117. [CrossRef]

111. Garrido-Gil, P.; Rodriguez-Perez, A.I. Bidirectional neural interaction between central dopaminergic and gut lesions in Parkinson's disease models. Mol. Neurobiol. 2018, 55, 7297-7316. [CrossRef]

112. Bradberry, C.W. Acute and chronic dopamine dynamics in a nonhuman primate model of recreational cocaine use. J. Neurosci. 2000, 20, 7109-7115. [CrossRef]

113. Shou, M.; Ferrario, C.R. Monitoring dopamine in vivo by microdialysis sampling and on-line CE-laser-induced fluorescence. Anal. Chem. 2006, 78, 6717-6725. [CrossRef]

114. Zhang, Y.; Picetti, R. Behavioral and neurochemical changes induced by oxycodone differ between adolescent and adult mice. Neuropsychopharmacology 2009, 34, 912-922. [CrossRef] [PubMed]

115. James, A.T.; Martin, A.J.P. Gas-liquid partition chromatography: The separation and micro-estimation of volatile fatty acids from formic acid to dodecanoic acid. Biochem. J. 1952, 50, 679-690. [CrossRef] [PubMed]

116. Huber, J.F.; Hulsman, J.A. A study of liquid chromatography in columns. The time of separation. Anal. Chim. Acta 1967, 38, 305-313. [CrossRef]

117. JOVE Science Education Database. High-performance liquid chromatography (HPLC). In Analytical Chemistry; JOVE: Cambridge, MA, USA, 2021.

118. Sasa, S.; Blank, C.L. Determination of serotonin and dopamine in mouse brain tissue by high performance liquid chromatography with electrochemical detection. Anal. Chem. 1977, 49, 354-359. [CrossRef]

119. Barwick, V.J. Sources of uncertainty in gas chromatography and high-performance liquid chromatography. J. Chromatogr. A 1999, 849, 13-33. [CrossRef]

120. Knox, J.H.; Jurand, J. Separation of catecholamines and their metabolites by adsorption, ion-pair and soap chromatography. J. Chromatogr. A 1976, 125, 89-101. [CrossRef]

121. Magnusson, O.; Nilsson, L.B. Simultaneous determination of dopamine, DOPAC and homovanillic acid. Direct injection of supernatants from brain tissue homogenates in a liquid chromatography-Electochemical detection system. J. Chromatogr. $B$ Biomed. Sci. Appl. 1980, 221, 237-247. [CrossRef]

122. Kilts, C.D.; Breese, G.R. Simultaneous quantification of dopamine, 5-hydroxytryptamine and four metabolically related compounds by means of reversed-phase high-performance liquid chromatography with electrochemical detection. J. Chromatogr. $B$ Biomed. Sci. Appl. 1981, 225, 347-357. [CrossRef]

123. Kontur, P.; Dawson, R. Manipulation of mobile phase parameters for the HPLC separation of endogenous monoamines in rat brain tissue. J. Neurosci. Methods 1984, 11, 5-18. [CrossRef]

124. Bartlett, W.A. Effects of mobile phase composition on the chromatographic and electrochemical behaviour of catecholamines and selected metabolites; Reversed-phase ion-paired high-performance liquid chromatography using multiple-electrode detection. $J$. Chromatogr. B Biomed. Sci. Appl. 1989, 493, 1-14. [CrossRef] 
125. Rossetti, Z.L.; Mercuro, G. A study of the parameters affecting flow gradient analysis of catecholamines, DOPA and DOPAC by ion pair liquid chromatography with electrochemical detection. Life Sci. 1983, 33, 2387-2397. [CrossRef]

126. Ungerstedt, U.; Pycock, C. Functional correlates of dopamine neurotransmission. Bull. Schweiz. Akad. Med. Wiss. 1974, 30, 44-55. [PubMed]

127. Ungerstedt, U.; Herrera-Marschitz, M. Dopamine synaptic mechanisms reflected in studies combining behavioural recordings and brain dialysis. In Advances in Dopamine Research, 1st ed.; Kohsaka, M., Shohmori, T., Eds.; Pergamon Press: Oxford, UK, 1982; pp. 219-231.

128. Imperato, A.; Di Chiara, G. Trans-striatal dialysis coupled to reverse phase high performance liquid chromatography with electrochemical detection: A new method for the study of the in vivo release of endogenous dopamine and metabolites. J. Neurosci. 1984, 4, 966-977. [CrossRef] [PubMed]

129. Chefer, V.I.; Thompson, A.C. Overview of brain microdialysis. Curr. Protoc. Neurosci. 2009, 7. [CrossRef]

130. Peters, A.; Palay, S.L. The Fine Structure of the Nervous System: The Neurons and Supporting Cells, 3rd ed.; Oxford University Press: New York, NY, USA, 1991.

131. Mitala, C.M.; Wang, Y. Impact of microdialysis probes on vasculature and dopamine in the rat striatum: A combined fluorescence and voltammetric study. J. Neurosci. Methods 2008, 174, 177-185. [CrossRef]

132. Jaquins-Gerstl, A.; Michael, A.C. Comparison of the brain penetration injury associated with microdialysis and voltammetry. J. Neurosci. Methods 2009, 183, 127-135. [CrossRef]

133. Morgan, M.E.; Singhal, D. Quantitative assessment of blood-brain barrier damage during microdialysis. J. Pharmacol. Exp. Ther. 1996, 277, 1167-1176.

134. Clapp-Lilly, K.L.; Roberts, R.C. An ultrastructural analysis of tissue surrounding a microdialysis probe. J. Neurosci. Methods 1999, 90, 129-142. [CrossRef]

135. Holson, R.R.; Gazzara, R.A. Declines in stimulated striatal dopamine release over the first $32 \mathrm{~h}$ following microdialysis probe insertion: Generalization across releasing mechanisms. Brain Res. 1998, 808, 182-189. [CrossRef]

136. Borland, L.M.; Shi, G. Voltammetric study of extracellular dopamine near microdialysis probes acutely implanted in the striatum of the anesthetized rat. J. Neurosci. Methods 2005, 146, 149-158. [CrossRef]

137. Yang, H.; Michael, A.C. In vivo fast-scan cyclic voltammetry of dopamine near microdialysis probes. In Electrochemical Methods for Neuroscience; Michael, A.C., Borland, L.M., Eds.; CRC Press/Taylor \& Francis: Boca Raton, FL, USA, 2007 ; Chapter 22.

138. Nesbitt, K.M.; Jaquins-Gerstl, A. Pharmacological mitigation of tissue damage during brain microdialysis. Anal. Chem. 2013, 85, 8173-8179. [CrossRef] [PubMed]

139. Nesbitt, K.M.; Varner, E.L. Microdialysis in the rat striatum: Effects of $24 \mathrm{~h}$ dexamethasone retrodialysis on evoked dopamine release and penetration injury. ACS Chem. Neurosci. 2015, 6, 163-173. [CrossRef]

140. Lee, W.H.; Ngernsutivorakul, T. Microfabrication and in vivo performance of a microdialysis probe with embedded membrane. Anal. Chem. 2016, 88, 1230-1237. [CrossRef]

141. Chen, N.H.; Lai, Y.J. Effects of different perfusion medium on the extracellular basal concentration of dopamine in striatum and medial prefrontal cortex: A zero-net flux microdialysis study. Neurosci. Lett. 1997, 225, 197-200. [CrossRef]

142. Osborne, P.G.; O'Connor, W.T. Effect of varying the ionic concentration of a microdialysis perfusate on basal striatal dopamine levels in awake rats. J. Neurochem. 1991, 56, 452-456. [CrossRef] [PubMed]

143. Krebs-Kraft, D.L.; Frantz, K.J. In Vivo Microdialysis: A Method for Sampling Extracellular Fluid in Discrete Brain Regions. In Handbook of Neurochemistry and Molecular Neurobiology; Lajtha, A., Baker, G., Eds.; Springer: Boston, MA, USA, 2007 ; pp. 219-256.

144. Vulto, A.G.; Sharp, T. Rapid postmortem increase in extracellular dopamine in the rat brain as assessed by brain microdialysis. $J$. Neurochem. 1988, 51, 746-749. [CrossRef] [PubMed]

145. Gonzalez-Mora, J.L.; Miadment, N.T. Post-mortem dopamine dynamics assessed by voltammetry and microdialysis. Brain Res. Bull. 1989, 23, 323-327. [CrossRef]

146. Takahashi, A.; Ikarashi, Y. Dopamine output upon death reflects intraneuronal aspects while alive: Accumulation of releasable dopamine during tetrodotoxin perfusion. Neurosci. Res. 1993, 18, 45-51. [CrossRef]

147. Shen, Y.; Ye, M.Y. Determination of the stability of dopamine in aqueous solutions by high performance liquid chromatography. $J$. Liq. Chromatogr. 1994, 17, 1557-1565. [CrossRef]

148. El-Sherbeni, A.A.; Stocco, M.R. Addressing the instability issue of dopamine during microdialysis: The determination of dopamine, serotonin, methamphetamine and its metabolites in rat brain. J. Chromatogr. A 2020, 1627, 461403. [CrossRef]

149. Ferris, M.J.; España, R.A. Dopamine transporters govern diurnal variation in extracellular dopamine tone. Proc. Natl. Acad. Sci. USA 2014, 111, E2751-E2759. [CrossRef]

150. Tang, A.; Bungay, P.M. Characterization of probe and tissue factors that influence interpretation of quantitative microdialysis experiments for dopamine. J. Neurosci. Methods 2003, 126, 1-11. [CrossRef]

151. Millar, J.; Armstrong-James, M. Polarographic assay of iontophoretically applied dopamine and low-noise unit recording using a multibarrel carbon fibre microelectrode. Brain Res. 1981, 205, 419-424. [CrossRef]

152. Millar, J.; Stamford, J.A. Electrochemical, pharmacological and electrophysiological evidence of rapid dopamine release and removal in the rat caudate nucleus following electrical stimulation of the median forebrain bundle. Eur. J. Phamarcol. 1985, 109, 341-348. [CrossRef] 
153. Fortin, S.M.; Cone, J.J. Sampling phasic dopamine signaling with fast-scan cyclic voltammetry in awake, behaving rats. Curr. Protoc. Neurosci. 2015, 70, 7.25.1-7.25.20. [CrossRef] [PubMed]

154. Robinson, D.L.; Venton, B.J. Detecting subsecond dopamine release with fast-scan cyclic voltammetry in vivo. Clin. Chem. 2003, 49, 1763-1773. [CrossRef] [PubMed]

155. Ewing, A.G.; Bigelow, J.C. Direct in vivo monitoring of dopamine released from two striatal compartments in the rat. Science 1983, 221, 169-171. [CrossRef]

156. Heien, M.L.; Johnson, M.A. Resolving neurotransmitters detected by fast-scan cyclic voltammetry. Anal. Chem. 2004, 76, 5697-5704. [CrossRef]

157. Howell, J.O.; Kuhr, W.G. Background subtraction for rapid scan voltammetry. J. Electroanal. Chem. Interfacial Electrochem. 1986, 209, 77-90. [CrossRef]

158. Oh, Y.; Park, C. Monitoring in vivo changes in tonic extracellular dopamine level by charge-balancing multiple waveform fast-scan cyclic voltammetry. Anal. Chem. 2016, 88, 10962-10970. [CrossRef] [PubMed]

159. Oh, Y.; Heien, M.L. Tracking tonic dopamine levels in vivo using multiple cyclic square wave voltammetry. Biosens. Bioelectron. 2018, 121, 174-182. [CrossRef] [PubMed]

160. Patriarchi, T.; Cho, J.R. Ultrafast neuronal imaging of dopamine dynapics with designed genetically encoded sensors. Science 2018, 360, eaat4422. [CrossRef]

161. Sun, F.; Zeng, J. A genetically encoded fluorescent sensor enables rapid and specific detection of dopamine in flies, fish, and mice. Cell 2018, 174, 481-496. [CrossRef] [PubMed]

162. Patriarchi, T.; Mohebi, A. An expanded palette of dopamine sensors for multiplex imaging in vivo. Nat. Methods 2020, 17, 1147-1155. [CrossRef]

163. Sun, F.; Zhou, J. Next-generation GRBA sensors for monitoring dopaminergic activity in vivo. Nat. Methods 2020, 17, 1156-1166. [CrossRef]

164. Labouesse, M.A.; Cola, R.B. GPCR-based dopamine sensors-A detailed guide to inform sensor choice for in vivo imaging. Int. J. Mol. Sci. 2020, 21, 8048. [CrossRef]

165. Mohebi, A.; Pettibone, J.R. Dissociable dopamine dynamics for learning and motivation. Nature 2019, 570, 65-70. [CrossRef]

166. Gerhardt, G.A.; Maloney, R.E. Microdialysis studies of basal levels and stimulus-evoked overflow of dopamine and metabolites in the striatum of young and aged Fischer 344 rats. Brain Res. 1999, 816, 68-77. [CrossRef]

167. Paulson, P.E.; Robinson, T.E. Regional differences in the effects of amphetamine withdrawal on dopamine dynamics in the striatum. Analysis of circadian patterns using automated on-line microdialysis. Neuropsychopharmacology 1996, 14, 325-337. [CrossRef]

168. Castañeda, T.R.; de Prado, B.M. Circadian rhythms of dopamine, glutamate and GABA in the striatum and nucleus accumbens of the awake rat: Modulation by light. J. Pineal Res. 2004, 36, 177-185. [CrossRef]

169. Smith, A.D.; Olson, R.J. Quantitative microdialysis of dopamine in the striatum: Effect of circadian variation. J. Neurosci. Methods 1992, 44, 33-41. [CrossRef]

170. Feenstra, M.G.; Botterblom, M.H. Dopamine and noradrenaline efflux in the prefrontal cortex in the light and dark period: Effects of novelty and handling and comparison to the nucleus accumbens. Neuroscience 2000, 100, 741-748. [CrossRef]

171. Xiao, L.; Becker, J.B. Quantitative microdialysis determination of extracellular striatal dopamine concentration in male and female rats: Effects of estrous cycle and gonadectomy. Neurosci. Lett. 1994, 180, 155-158. [CrossRef]

172. Dazzi, L.; Seu, E. Estrous cycle-dependent changes in basal and ethanol-induced activity of cortical dopaminergic neurons in the rat. Neuropsychopharmacology 2007, 32, 892-901. [CrossRef] [PubMed]

173. Aubele, T.; Kritzer, M.F. Gonadectomy and hormone replacement affects in vivo basal extracellular dopamine levels in the prefrontal cortex but not motor cortex of adult male rates. Cereb. Cortex 2011, 21, 222-232. [CrossRef]

174. Scheller, C.; Arendt, G. Increased dopaminergic neurotransmission in therapy-naïve asymptomatic HIV patients is not associated with adaptive changes at the dopaminergic synapses. J. Neural Transm. 2010, 117, 699-705. [CrossRef] [PubMed]

175. Kesby, J.P.; Markous, A. The effects of HIV-1 regulatory TAT protein expression on brain reward function, response to psychostimulants and delay-dependent memory in mice. Neuropharmacology 2016, 109, 205-215. [CrossRef] [PubMed]

176. Strauss, M.; O'Donovan, B. $\left[{ }^{3} \mathrm{H}\right]$ dopamine uptake through the dopamine and norepinephrine transporters is decreased in the prefrontal cortex of transgenic mice expressing HIV-1 transactivator of transcription protein. J. Pharmacol. Exp. Ther. 2020, 374, 241-251. [CrossRef]

177. WHO Case Definitions of HIV for Surveillance and Revised Clinical Staging and Immunological Classification of HIV-Related Disease in Adults and Children. Available online: https://www.who.int/hiv/pub/guidelines/HIVstaging150307.pdf (accessed on 4 July 2021).

178. Kesby, J.P.; Markou, A. Effects of HIV/TAT protein expression and chronic selegiline treatment on spatial memory, reversal learning and neurotransmitter levels in mice. Behav. Brain Res. 2016, 311, 131-140. [CrossRef]

179. Romley, J.A.; Juday, T. Early HIV treatment led to life expectancy gains valued at $\$ 80$ billion for people infected in $1996-2009$. Health Aff. 2014, 33, 370-377. [CrossRef]

180. Teeraananchai, S.; Kerr, S.J. Life expectancy of HIV-positive people after starting combination antiretroviral therapy: A metaanalysis. HIV Med. 2017, 18, 256-266. [CrossRef] [PubMed] 
181. Czub, S.; Koutsilieri, E. Enhancement of central nervous system pathology in early simian immunodeficiency virus infection by dopaminergic drugs. Acta Neuropathol. 2001, 101, 85-91. [PubMed]

182. Koutsilieri, E.; Sopper, S. Parkinsonism in HIV dementia. J. Neural Trasm. 2002, 109, 767-775. [CrossRef]

183. Jenuwein, M.; Scheller, C. Dopamine deficits and regulation of the cAMP second messenger system in brains of simian immunodeficiency virus-infected rhesus monkeys. J. Neurovirol. 2004, 10, 163-170. [CrossRef] [PubMed]

184. Scheller, C.; Sopper, S. Early impairment in dopaminergic neurotransmission in brains of SIV-infected rhesus monkeys due to microglia activation. J. Neurochem. 2005, 95, 377-387. [CrossRef]

185. Ferris, M.J.; Frederick-Duus, D. In vivo microdialysis in awake, freely moving rats demonstrates HIV-1 Tat-induced alterations in dopamine transmission. Synapse 2009, 63, 181-185. [CrossRef]

186. Horn, A.; Scheller, C. The dopamine-related polymorphisms BDNF, COMT, DRD2, DRD3, and DRD4 are not linked with changes in CSF dopamine levels and frequency of HIV infection. J. Neural Transm. 2017, 124, 501-509. [CrossRef] [PubMed]

187. Javadi-Paydar, M.; Roscoe, R.F., Jr. HIV-1 and cocaine disrupt dopamine reuptake and medium spiny neurons in female rat striatum. PLoS ONE 2017, 12, e0188404. [CrossRef]

188. Saloner, R.; Cherner, M. Lower CSF homovanillic acid relates to higher burden of neuroinflammation and depression in people with HIV disease. Brain Behav. Immun. 2020, 90, 353-363. [CrossRef] [PubMed]

189. Denton, A.R.; Mactutus, C.F. Chronic SSRI treatment reverses HIV-1 protein-mediated synaptodendritic damage. J. Neurovirol. 2021, 27, 403-421. [CrossRef] [PubMed]

190. Antinori, A.; Arendt, G. Updated research nosology for HIV-associated neurocognitive disorders. Neurology 2007, 69, 1789-1799. [CrossRef] [PubMed]

191. Heaton, R.K.; Franklin, D.R. Neurocognitive change in the era of HIV combination antiretroviral therapy: The longitudinal CHARTER study. Clin. Infect. Dis. 2015, 60, 473-480. [CrossRef] [PubMed]

192. Sacktor, N.; Skolasky, R.L. Prevalence of HIV-associated neurocognitive disorders in the Multicenter AIDS Cohort Study. Neurology 2016, 86, 334-340. [CrossRef]

193. Rubin, L.H.; Maki, P.M. Cognitive trajectories over 4 years among HIV-infected women with optimal viral suppression. Neurology 2017, 89, 1594-1603. [CrossRef]

194. Gott, C.; Gates, T. Cognitive change trajectories in virally suppressed HIV-infected individuals indicate high prevalence of disease activity. PLoS ONE 2017, 12, e0171887. [CrossRef]

195. McLaurin, K.A.; Li, H. Disruption of timing: NeuroHIV progression in the post-cART era. Sci. Rep. 2019, 9, 827. [CrossRef]

196. Cysique, L.A.; Maruff, P. Prevalence and pattern of neuropsychological impairment in human immunodeficiency virusinfected/acquired immunodeficiency syndrome (HIV / AIDS) patients across pre- and post-highly active antiretroviral therapy eras: A combined study of two cohorts. J. Neurovirol. 2004, 10, 350-357. [CrossRef]

197. Garvey, L.J.; Yerrakalva, D. Correlations between computerized battery testing and a memory questionnaire for identification of neurocognitive impairment in HIV type 1-infected subjects on stable antiretroviral therapy. AIDS Res. Hum. Retrovir. 2009, 25, 765-769. [CrossRef]

198. Bertrand, S.J.; Mactutus, C.F. HIV-1 proteins dysregulate motivational processes and dopamine circuitry. Sci. Rep. 2018, 8, 7869. [CrossRef] [PubMed]

199. Bhatia, M.S.; Munjal, S. Prevalence of depression in people living with HIV/AIDS undergoing ART and factors associated with it. J. Clin. Diagn Res. 2014, 8, WC01-WC04. [CrossRef] [PubMed]

200. Do, A.N.; Rosenberg, E.S. Excess burden of depression among HIV-infected persons receiving medical care in the United States: Data from the medical monitoring project and the behavioral risk factor surveillance system. PLoS ONE 2014, 9, e92842. [CrossRef] [PubMed]

201. Hoffman, H.S.; Searle, J.L. Acoustic variables in the modification of startle reaction in the rat. J. Comp. Physiol. Psychol. 1965, 60, 53-58. [CrossRef]

202. Ison, J.R.; Hammond, G.R. Modification of the startle reflex in the rat by changes in the auditory and visual environments. J. Comp. Phsyiol. Psychol. 1971, 75, 435-452. [CrossRef]

203. Hoffman, H.S.; Ison, J.R. Reflex modification in the domain of startle: I. Some empirical findings and their implications for how the nervous system processes sensory input. Psychol. Rev. 1980, 87, 175-189. [CrossRef]

204. Braff, D.; Stone, C. Prestimulus effects on human startle reflex in normal and schizophrenics. Psychophysiology 1978, 15, $339-343$. [CrossRef]

205. Hoenig, K.; Hochrein, A. Impaired prepulse inhibition of acoustic startle in obsessive-compulsive disorder. Biol. Psychiatry 2005, 57, 1153-1158. [CrossRef]

206. Ahmari, S.E.; Risbrough, V.B. Impaired sensorimotor gating in unmedicated adults with obsessive-compulsive disorder. Neuropsychopharmacology 2012, 37, 1216-1223. [CrossRef]

207. Swerdlow, N.R.; Paulsen, J. Impaired prepulse inhibition of acoustic and tactile startle response in patients with Huntington's disease. J. Neurol. Neurosurg. Psychiatry 1995, 58, 192-200. [CrossRef]

208. Minassian, A.; Henry, B.L. Prepulse inhibition in HIV-associated neurocognitive disorders. J. Int. Neuropsychol. Soc. 2013, 19, 709-717. [CrossRef]

209. Moran, L.M.; Booze, R.M. Time and time again: Temporal processing demands implicate perceptual and gating deficits in the HIV-1 transgenic rat. J. Neuroimmune Pharmacol. 2013, 8, 988-997. [CrossRef] 
210. Bachis, A.; Forcelli, P. Expression of p120 in mice evokes anxiety behavior: Co-occurrence with increased dendritic spines and brain-derived neurotrophic factor in the amygdala. Brain Behav. Immun. 2016, 54, 170-177. [CrossRef]

211. McLaurin, K.A.; Booze, R.M. Temporal processing demands in the HIV-1 transgenic rat: Amodal gating and implications for diagnostics. Int. J. Dev. Neurosci. 2017, 57, 12-20. [CrossRef]

212. McLaurin, K.A.; Booze, R.M. Progression of temporal processing deficits in the HIV-1 transgenic rat. Sci. Rep. $2016,6,32831$. [CrossRef] [PubMed]

213. McLaurin, K.A.; Booze, R.M. Evolution of the HIV-1 transgenic rat: Utility in assessing the progression of HIV-1-associated neurocognitive disorders. J. Neurovirol. 2018, 24, 229-245. [CrossRef]

214. McLaurin, K.A.; Booze, R.M. Diagnostic and prognostic biomarkers for HAND. J. Neurovirol. 2019, 25, 686-701. [CrossRef]

215. Davis, M.; Gendelman, D.S. A primary acoustic startle circuit: Lesion and stimulation studies. J. Neurosci. 1982, 2, 791-805. [CrossRef] [PubMed]

216. Koch, M. The neurobiology of startle. Prog. Neurobiol. 1999, 59, 107-128. [CrossRef]

217. Fendt, M.; Li, L. Brain stem circuits mediating prepulse inhibition of the startle reflex. Psychopharmacology 2001, 156, 216-224. [CrossRef] [PubMed]

218. Di Chiara, G.; Porceddu, M.L. Evidence for dopamine receptors mediating sedation in the mouse brain. Nature 1976, 264, 564-567. [CrossRef] [PubMed]

219. Goodale, D.P.; Rusterholz, D.B. Neurochemical and behavioral evidence for a selective presynaptic dopamine receptor agonist. Science 1980, 210, 1141-1143. [CrossRef]

220. Campeau, S.; Davis, M. Prepulse inhibition of the acoustic startle reflect using visual and auditory prepulses: Disruption by apomorphine. Psychopharmacology 1995, 117, 267-274. [CrossRef] [PubMed]

221. Jones, C.K.; Shannon, H.E. Effects of scopolamine in comparison with apomorphine and phencyclidine on prepulse inhibition in rats. Eur. J. Pharmacol. 2000, 391, 105-112. [CrossRef]

222. Mansbach, R.S.; Geyer, M.A. Dopaminergic stimulation disrupts sensorimotor gating in the rat. Psychopharmacology 1988, 94 , 507-514. [CrossRef]

223. Zavitsanou, K.; Cranney, J. Dopamine antagonists in the orbital prefrontal cortex reduce prepulse inhibition of the acoustic startle reflex in the rat. Pharmacol. Biochem. Behav. 1999, 63, 55-61. [CrossRef]

224. Rodrigues, S.; Salum, C. Dorsal striatum D1-expressing neurons are involved with sensorimotor gating on prepulse inhibition test. J. Psychopharmacol. 2017, 31, 505-513. [CrossRef] [PubMed]

225. Ellenbroek, B.A.; Budde, S. Prepulse inhibition and latent inhibition: The role of dopamine in the medial prefrontal cortex. Neuroscience 1996, 75, 535-542. [CrossRef]

226. Ungerstedt, U. 6-hydroxy-dopamine induced degeneration of central monoamine neurons. Eur. J. Pharmacol. 1968, 5, 107-110. [CrossRef]

227. Bloom, F.E.; Algeri, S. Lesions of central norepinephrine terminals with 6-OH-dopamine: Biochemistry and fine structure. Science 1969, 166, 1284-1286. [CrossRef]

228. Schwarzkopf, S.B.; Mitra, T. Sensory gating in rats depleted of dopamine as neonates: Potential relevance to findings in schizophrenic patients. Biol. Psychiatry 1992, 31, 759-773. [CrossRef]

229. Bubser, M.; Koch, M. Prepulse inhibition of the acoustic startle response of rats is reduced by 6-hydroxydopamine lesions of the medial prefrontal cortex. Psychopharmacology 1994, 113, 487-492. [CrossRef]

230. Fuster, J.M. The Prefrontal Cortex, 4th ed.; Academic Press: New York, NY, USA, 2008.

231. Sohlberg, M.M.; Mateer, C.A. Effectiveness of an attention-training program. J. Clin. Exp. Neuropscyhol. 1987, 9, 117-130. [CrossRef]

232. Sohlberg, M.M.; Mateer, C.A. Introduction to Cognitive Rehabilityation: Theory and Practice; Guilford Press: New York, NY, USA, 1989.

233. Moran, L.M.; Booze, R.M. Modeling deficits in attention, inhibition, and flexibility in HAND. J. Neuroimmune Pharmacol. 2014, 9 , 508-521. [CrossRef]

234. Lew, B.J.; McDermott, T.J. Neural dynamics of selective attention deficits in HIV-associated neurocognitive disorder. Neurology 2018, 91, e1860-e1869. [CrossRef] [PubMed]

235. McLaurin, K.A.; Moran, L.M. Selective estrogen receptor $\beta$ agonists: A therapeutic approach for HIV-1 associated neurocognitive disorders. J. Neuroimmune Pharmacol. 2020, 15, 264-279. [CrossRef]

236. Hinkin, C.H.; Castellon, S.A. Dual task performance in HIV-1 infection. J. Clin. Exp. Neuropsychol. 2000, 22, 16-24. [CrossRef]

237. Williams, S.M.; Goldman-Rakic, P.S. Widespread origin of the primate mesofrontal dopamine system. Cereb. Cortex 1998, 8 , 321-345. [CrossRef]

238. Granon, S.; Passetti, F. Enhanced and impaired attentional performance after infusion of D1 dopaminergic receptor agents into rat prefrontal cortex. J. Neurosci. 2000, 20, 1208-1215. [CrossRef]

239. Rose, J.; Schiffer, A.M. The role of dopamine in maintenance and distractability of attention in the "prefrontal cortex" of pigeons. Neuroscience 2010, 167, 232-237. [CrossRef]

240. Pezze, M.A.; Dalley, J.W. Differential roles of dopamine D1 and D2 receptors in the nucleus accumbens in attentional performance on the five-choice serial reaction time task. Neuropsychopharmacology 2007, 32, 273-283. [CrossRef] [PubMed]

241. Caballero, M.; Núnez, F. Caffeine improves attention deficit in neonatal 6-OHDA lesioned rats, an animal model of attention deficit hyperactivity disorder (ADHD). Neurosci. Lett. 2011, 494, 44-48. [CrossRef] 
242. Bouchatta, O.; Manouze, H. Neonatal 6-OHDA lesion model in mouse induces Attention-Deficit/Hyperactivity Disorder (ADHD)-like behaviour. Sci. Rep. 2018, 8, 15349. [CrossRef] [PubMed]

243. Bouchatta, O.; Manouze, H. Neonatal 6-OHDA lesion model in mouse induces cognitive dysfunctions of AttentionDeficit/Hyperactivity Disorder (ADHD) during young age. Front. Behav. Neurosci. 2020, 14, 27. [CrossRef]

244. Oke, A.F.; Adams, R.N. Selective attention dysfunctions in adult rats neonatally treated with 6-hydroxydopamine. Pharmacol. Biochem. Behav. 1978, 9, 429-432. [CrossRef]

245. Crofts, H.S.; Dalley, J.W. Differential effects of 6-OHDA lesions of the frontal cortex and caudate nucleus on the ability to acquire an attentional set. Cereb. Cortex 2001, 11, 1015-1026. [CrossRef]

246. Roberts, A.C.; De Salvia, M.A. 6-Hydroxydopamine lesions of the prefrontal cortex in monkeys enhance performance on an analog of the Wisconsin Card Sort Test: Possible interactions with subcortical dopamine. J. Neurosci. 1994, 14, 2531-2544. [CrossRef]

247. Decamp, E.; Schneider, J.S. Attention and executive function deficits in chronic low-dose MPTP-treated non-human primates. Eur. J. Neurosci. 2004, 20, 1371-1378. [CrossRef] [PubMed]

248. Marin, R.S. Apathy: A neuropsychiatric syndrome. J. Neuropsychiatry Clin. Neurosci. 1991, 3, 243-254.

249. Levy, R.; Dubois, B. Apathy and the functional anatomy of the prefrontal cortex-basal ganglia circuits. Cereb. Cortex 2006, 16, 916-928. [CrossRef]

250. Clarke, D.E.; Ko, J.Y. Are the available apathy measures reliable and valid? A review of the psychometric evidence. J. Psychosom. Res. 2011, 70, 73-97. [CrossRef]

251. Marin, R.S.; Biedrzycki, R.C. Reliability and validity of the Apathy Evaluation Scale. Psychiatry Res. 1991, 38, 143-162. [CrossRef]

252. Cummings, J.L.; Mega, M. The Neuropsychiatric Inventory: Comprehensive assessment of psychopathology in dementia. Neurology 1994, 44, 2308-2314. [CrossRef]

253. Oakeshott, S.; Port, R. A mixed fixed ratio/progressive ratio procedure reveals an apathy phenotype in the BAC HD and the z_Q175 KI mouse models of Huntington's disease. PLoS Curr. 2012, 4, e4f972cffe82c0. [CrossRef] [PubMed]

254. McLaurin, K.A.; Bertrand, S.J. S-equol mitigates motivational deficits and dysregulation associated with HIV-1. Sci. Rep. 2021, 11, 11870. [CrossRef] [PubMed]

255. Zhao, Q.F.; Tan, L. The prevalence of neuropsychiatric symptoms in Alzheimer's disease: Systematic review and meta-analysis. J. Affect. Disord. 2016, 190, 264-271. [CrossRef]

256. den Brok, M.G.; van Dalen, J.W. Apathy in Parkinson's disease: A systematic review and meta-analysis. Mov. Disord. 2015, 30, 759-769. [CrossRef] [PubMed]

257. Tate, D.; Paul, R.H. The impact of apathy and depression on quality of life in patients infected with HIV. AIDS Patient Care STDs 2003, 17, 115-120. [CrossRef] [PubMed]

258. Kamat, R.; Morgan, E. Implications of apathy and depression for everyday functioning in HIV/AIDS in Brazil. J. Affect. Disord. 2013, 150, 1069-1075. [CrossRef]

259. Panos, S.E.; Del Re, A.C. The impact of neurobehavioral features on medication adherence in HIV: Evidence from longitudinal models. AIDS Care 2014, 26, 79-86. [CrossRef] [PubMed]

260. Kamat, R.; Doyle, K.L. Neurobehavioral disturbances during acute and early HIV infection. Cogn Behav Neurol. 2016, 29, 1-10. [CrossRef]

261. Bonelli, R.M.; Cummings, J.L. Frontal-subcortical circuitry and behavior. Dialogues Clin. Neurosci. 2007, 9, 141-151. [PubMed]

262. Selemon, L.D.; Goldman-Rakic, P.S. Longitudinal topography and interdigitation of corticostriatal projections in the rhesus monkey. J. Neurosci. 1985, 5, 776-794. [CrossRef]

263. Critchley, H.D. Neural mechanisms of autonomic, affective, and cognitive integration. J. Comp. Neurol. 2005, 493, 154-166. [CrossRef] [PubMed]

264. Drui, G.; Carnicella, S. Loss of dopaminergic nigrostriatal neurons accounts for the motivational and affective deficits in Parkinson's disease. Mol. Psychiatry. 2014, 19, 358-367. [CrossRef]

265. Favier, M.; Duran, T. Pramipexole reverses Parkinson's disease-related motivational deficits in rats. Mov. Disord. 2014, 29, 912-920. [CrossRef] [PubMed]

266. Carnicella, S.; Drui, G. Implication of dopamine D3 receptor activation in the reversion of Parkinson's disease-related motivational deficits. Transl. Psychiatry 2014, 4, e401. [CrossRef]

267. Brown, C.A.; Campbell, M.C. Dopamine pathway loss in nucleus accumbens and ventral tegmental area predicts apathetic behavior in MPTP-lesioned monkeys. Exp. Neurol. 2012, 236, 190-197. [CrossRef] [PubMed]

268. Fitzpatrick, C.M.; Runegaard, A.H. Differential effects of chemogenetic inhibition of dopamine and norepinephrine neurons in the mouse 5-choice serial reaction time task. Prog. Neuropsychopharmacol. Biol. Psychiatry 2019, 90, 264-276. [CrossRef]

269. Guidelines for the Use of Antiretroviral Agents in Adults and Adolescents Living with HIV. Available online: https://clinicalinfo. hiv.gov/en/guidelines/adult-and-adolescent-arv/whats-new-guidelines (accessed on 4 December 2020).

270. Letendre, S.; Marquie-Beck, J. Validation of the CNS Penetration-Effectiveness rank for quantifying antiretroviral penetration into the central nervous system. Arch. Neurol. 2008, 65, 65-70. [CrossRef]

271. Morlese, J.F.; Qazi, N.A. Nevirapine-induced neuropsychiatric complications, a class effect of non-nucleoside reverse transcriptase inhibitors? AIDS 2002, 16, 1840-1841. [CrossRef] [PubMed]

272. Wise, M.E.J.; Mistry, K. Drug points: Neuropsychiatric complications of nevirapine treatment. BMJ 2002, 324, 879. [CrossRef] [PubMed] 
273. Rihs, T.A.; Begley, K. Efavirenz and chronic neuropsychiatric symptoms: A cross-sectional case control study. HIV Med. 2006, 7, 544-548. [CrossRef] [PubMed]

274. Cespedes, M.S.; Aberg, J.A. Neuropsychiatric complications of antiretroviral therapy. Drug Saf. 2006, 29, 865-874. [CrossRef] [PubMed]

275. Treisman, G.J.; Soudry, O. Neuropsychiatric Effects of HIV Antiviral Medications. Drug Saf. 2016, 39, 945-957. [CrossRef]

276. Gatch, M.B.; Kozlenkov, A. The HIV antiretroviral drug efavirenz has LSD-like properties. Neuropsychopharmacology 2013, 38, 2373-2384. [CrossRef] [PubMed]

277. Dalwadi, D.A.; Kim, S. Molecular mechanisms of serotonergic action of the HIV-1 antiretroviral efavirenz. Pharmacol. Res. 2016, 110, 10-24. [CrossRef] [PubMed]

278. Huang, R.; Chen, Z. The dual modulatory effects of efavirenz on GABAA receptors are mediated via two distinct sites. Neuropharmacology 2017, 121, 167-178. [CrossRef] [PubMed]

279. Möller, M.; Fourie, J. Efavirenz exposure, alone and in combination with known drugs of abuse, engenders addictive-like bio-behavioural changes in rats. Sci. Rep. 2018, 8, 12837. [CrossRef]

280. Cavalcante, G.I.T.; Chaves Filho, A.J.M. HIV antiretroviral drug Efavirenz induces anxiety-like and depression-like behavior in rats: Evaluation of neurotransmitter alterations in the striatum. Eur. J. Pharmacol. 2017, 799, 7-15. [CrossRef]

281. Overton, D.A. Major theories of state-dependent learning. In Drug Discrimination and State Dependent Learning; Ho, B.T., Richards, D.W., Eds.; Academic Press: New York, NY, USA, 1978; pp. 283-309.

282. Appel, J.B.; Kuhn, D.M. Dual receptor mediation of the discriminative stimulus properties of pentazocine. In Drug Discrimination and State Dependent Learning; Ho, B.T., Richards, D.W., Eds.; Academic Press: New York, NY, USA, 1978; pp. 149-160.

283. Anagnostaras, S.G.; Robinson, T.E. Sensitization to the psychomotor stimulant effects of amphetamine: Modulation by associative learning. Behavioral. Neurosci. 1996, 110, 1397-1414. [CrossRef]

284. Harrod, S.B.; Mactutus, C.F. Intra-accumbal Tat1-72 alters acute and sensitized responses to cocaine. Pharmacol. Biochem. Behav. 2008, 90, 723-729. [CrossRef] [PubMed]

285. Robinson, T.E.; Jurson, P.A. Persistent sensitization of dopamine neurotransmission in ventral striatum (nucleus accumbens) produced by prior experience with (+)-amphetamine: A microdialysis study in freely moving rats. Brain Res. 1988, 462, 211-222. [CrossRef]

286. Heidbreder, C.A.; Thompson, A.C. Role of extracellular dopamine in the initiation and long-term expression of behavioral sensitization to cocaine. J. Pharmacol. Exp. Ther. 1996, 278, 490-502. [PubMed]

287. Weeks, J.R. Experimental morphine addiction: Method for automatic intravenous injections in unrestrained rats. Science 1962, 138, 143-144. [CrossRef]

288. Pickens, R. Self-administration of stimulants by rats. Int. J. Addict. 1968, 3, 215-221. [CrossRef]

289. De Guglielmo, G.; Fu, Y. Increases in compulsivity, inflammation, and neural injury in HIV transgenic rats with escalated methamphetamine self-administration under extended-access conditions. Brain Res. 2020, 1726, 146502. [CrossRef]

290. Zanni, G.; DeSalle, M.J. Female and male rats readily consume and prefer oxycodone to water in a chronic, continuous access, two-bottle oral voluntary paradigm. Neuropharmacology 2020, 167, 107978. [CrossRef]

291. O'Connor, E.C.; Chapman, K. The predictive validity of the rat self-administration model for abuse liability. Neurosci. Biobehav. Rev. 2011, 35, 912-938. [CrossRef]

292. Clark, R.; Schuster, C.R. Instrumental conditioning of jugular self-infusion in the rhesus monkey. Science 1961, 133, 1829-1830. [CrossRef] [PubMed]

293. Illenberger, J.M.; Harrod, S.B. HIV Infection and Neurocognitive Disorders in the Context of Chronic Drug Abuse: Evidence for Divergent Findings Dependent upon Prior Drug History. J. Neuroimmune Pharmacol. 2020, 15, 715-728. [CrossRef]

294. Bardo, M.T.; Bevins, R.A. Conditioned place preference: What does it add to our preclinical understanding of drug reward? Psychopharmacology 2000, 153, 31-43. [CrossRef] [PubMed]

295. Nomikos, G.G.; Spyraki, C. Cocaine-induced place conditioning: Importance of route of administration and other procedural variables. Psychopharmacology 1988, 94, 119-125. [CrossRef]

296. Meehan, S.M.; Schechter, M.D. LSD produces conditioned place preference in male but not female fawn hooded rats. Pharmacol. Biochem. Behav. 1998, 59, 105-108. [CrossRef]

297. Prus, A.J.; James, J.R. Conditioned Place Preference. In Methods of Behavior Analysis in Neuroscience, 2nd ed.; Buccafusco, J.J., Ed.; CRC Press/Taylor \& Francis: Boca Raton, FL, USA, 2009.

298. Neisewander, J.L.; McDougall, S.A. Conditioned taste aversion and place preference with buspirone and gepirone. Psychopharmacology 1990, 100, 485-490. [CrossRef] [PubMed]

299. Orlando, G.; Brunetti, L. Ritonavir and Saquinavir directly stimulate anterior pituitary prolactin secretion, in vitro. Int. J. Immunopathol. Pharmacol. 2002, 15, 65-68. [CrossRef] [PubMed]

300. Polazzi, E.; Monti, B. Microglia and neuroprotection: From in vitro studies to therapeutic applications. Prog. Neurobiol. 2010, 92, 293-315. [CrossRef]

301. Murabe, Y.; Sano, Y. Morphological studies on neuroglia. VI. Postnatal development of microglial cells. Cell Tissue Res. 1982, 225, 469-485. [CrossRef] [PubMed]

302. Perry, V.H.; Hume, D.A. Immunohistochemical localization of macrophages and microglia in the adult and developing mouse brain. Neuroscience 1985, 15, 313-326. [CrossRef] 
303. Davalos, D.; Grutzendler, J. ATP mediates rapid microglial response to local brain injury in vivo. Nat. Neurosci. 2005, 8, 752-758. [CrossRef]

304. Nimmerjahn, A.; Kirchhoff, F. Resting microglial cells are highly dynamic surveillants of brain parenchyma in vivo. Science 2005, 308, 1314-1318. [CrossRef] [PubMed]

305. Wake, H.; Moorhouse, A.J. Resting microglia directly monitor the functional state of synapses in vivo and determine the fate of ischemic terminals. J. Neurosci. 2009, 29, 3974-3980. [CrossRef]

306. Tremblay, M.E.; Lowery, R.L. Microglial interactions with synapses are modulated by visual experience. PLoS Biol. 2010, 8, e1000527. [CrossRef] [PubMed]

307. Lawson, L.J.; Perry, V.H. Heterogeneity in the distribution and morphology of microglia in the normal adult mouse brain. Neuroscience 1990, 39, 151-170. [CrossRef]

308. De Biase, L.M.; Schuebel, K.E. Local cues establish and maintain region-specific phenotypes of basal ganglia microglia. Neuron 2017, 95, 341-356. [CrossRef]

309. Färber, K.; Pannasch, U. Dopamine and noradrenaline control distinct functions in rodent microglial cells. Mol. Cell. Neurosci. 2005, 29, 128-138. [CrossRef]

310. Mastroeni, D.; Grover, A. Microglial responses to dopamine in a cell culture model of Parkinson's disease. Neurobiol. Aging 2009, 30, 1805-1817. [CrossRef]

311. Huck, J.H.J.; Freyer, D. De novo expression of dopamine D2 receptors on microglia after stroke. J. Cereb. Blood Flow Metab. 2015, 35, 1804-1811. [CrossRef]

312. Fan, Y.; Chen, Z. Differential regulation of adhesion and phagocytosis of resting and activated microglia by dopamine. Front. Cell. Neurosci. 2018, 12, 309. [CrossRef]

313. Squarzoni, P.; Oller, G. Microglia modulate wiring of the embryonic forebrain. Cell Rep. 2014, 8, 1271-1279. [CrossRef]

314. Paolicelli, R.C.; Bolasco, G. Synaptic pruning by microglia is necessary for normal brain development. Science 2011, 333, 1456-1458. [CrossRef]

315. Schafer, D.P.; Lehrman, E.K. Microglia sculpt postnatal neural circuits in an activity and complement-dependent manner. Neuron 2012, 74, 691-705. [CrossRef]

316. Weinhard, L.; di Barolomei, G. Microglia remodel synapses by presynaptic trogocytosis and spine head filopodia induction. Nat. Commun. 2018, 9, 1228. [CrossRef] [PubMed]

317. Parkhurst, C.N.; Yang, G. Microglia promote learning-dependent synapse formation through brain-derived neurotrophic factor. Cell 2013, 155, 1596-1609. [CrossRef]

318. Mallya, A.P.; Wang, H.D. Microglial pruning of synapses in the prefrontal cortex during adolescence. Cereb. Cortex 2019, 29, 1634-1643. [CrossRef]

319. Choudhury, M.E.; Miyanishi, K. Phagocytic elimination of synapses by microglia during sleep. Glia 2020, 68, 44-59. [CrossRef]

320. Lim, S.H.; Park, E. Neuronal synapse formation induced by microglia and interleukin 10. PLoS ONE 2013, 8, e81218. [CrossRef] [PubMed]

321. Miyamoto, A.; Wake, H. Microglia contact induces synapse formation in developing somatosensory cortex. Nat. Commun. 2016, 7 , 12540. [CrossRef] [PubMed]

322. Sierra, A.; Encinas, J.M. Microglia shape adult hippocampal neurogenesis through apoptosis-coupled phagocytosis. Cell Stem Cell 2010, 7, 483-495. [CrossRef]

323. Stefani, J.; Tschesnokowa, O. Disruption of the microglial ADP receptor P2Y 13 enhances adult hippocampal neurogenesis. Front. Cell. Neurosci. 2018, 12, 134. [CrossRef] [PubMed]

324. Diaz-Aparicio, I.; Paris, I. Microglia actively remodel adult hippocampal neurogenesis through the phagocytosis secretome. J. Neurosci. 2020, 40, 1453-1482. [CrossRef] [PubMed]

325. Freund, T.F.; Powell, J.F. Tyrosine hydroxylase-immunoreactive boutons in synaptic contact with identified striatonigral neurons, with particular reference to dendritic spines. Neuroscience 1984, 13, 1189-1215. [CrossRef]

326. Yao, W.D.; Spealman, R.D. Dopaminergic signaling in dendritic spines. Biochem. Pharmacol. 2008, 75, 2055-2069. [CrossRef] [PubMed]

327. Meredith, G.E.; Ypma, P. Effects of dopamine depletion on the morphology of medium spiny neurons in the shell and core of the rat nucleus accumbens. J. Neurosci. 1995, 15, 3808-3820. [CrossRef]

328. Neely, M.D.; Schmidt, D.E. Cortical regulation of dopamine depletion-induced dendritic spine loss in striatal medium spiny neurons. Neuroscience 2007, 149, 457-464. [CrossRef] [PubMed]

329. Ingham, C.A.; Hood, S.H. Morphological changes in the rat neostriatum after unilateral 6-hydroxydopamine injections into the nigrostriatal pathway. Exp. Brain Res. 1993, 93, 17-27. [CrossRef]

330. Ingham, C.A.; Hood, S.H. Plasticity of synapses in the rat neostriatum after unilateral lesion of the nigrostriatal dopaminergic pathway. J. Neurosci. 1998, 18, 4732-4743. [CrossRef]

331. Thompson, K.A.; Cherry, C.L. Brain cell reservoirs of latent virus in presymptomatic HIV-infected individuals. Am. J. Pathol. 2011, 179, 1623-1629. [CrossRef]

332. Ko, A.; Kang, G. Macrophages but not astrocytes harbor HIV DNA in the brains of HIV-1-infected aviremic individuals on suppressive antiretroviral therapy. J. Neuroimmune Pharmacol. 2019, 14, 110-119. [CrossRef] 
333. Anthony, I.C.; Ramage, S.N. Influence of HAART on HIV-related CNS disease and neuroinflammation. J. Neuropathol. Exp. Neurol. 2005, 64, 529-536. [CrossRef]

334. Li, H.; Mactutus, C.F. HIV-1 expression in human medial prefrontal cortex: Association with HAND. In Proceedings of the International Symposium for NeuroVirology, Virtual, 2-4 June 2021. Abstract Number 52.

335. Thangaraj, A.; Chivero, E.T. HIV Tat-mediated microglial senescence: Role of SIRT3-dependent mitochondrial oxidative stress Redox Biol. 2021, 40, 101843. [CrossRef] [PubMed]

336. Gelman, B.B.; Lisinicchia, J.G. Prefrontal dopaminergic and enkephalinergic synaptic accommodation in HIV-associated neurocognitive disorders and encephalitis. J. Neuroimmune Pharmacol. 2012, 7, 686-700. [CrossRef]

337. Roscoe, R.F.; Mactutus, C.F. HIV-1 transgenic female rat: Synaptodendritic alterations of medium spiny neurons in the nucleus accumbens. J. Neuroimmune Pharmacol. 2014, 9, 642-653. [CrossRef] [PubMed]

338. Miller, D.R.; Shaerzadeh, F. HIV-1 Tat regulation of dopamine transmission and microglial reactivity is brain region specific. Glia 2018, 66, 1915-1928. [CrossRef] [PubMed]

339. Duan, M.; Yao, H. HIV-1 Tat disrupts CX3CL1-CX3CR1 axis in microglia via the NF-KBYY1 pathway. Curr. HIV Res. 2014, 12, 189-200. [CrossRef] [PubMed]

340. Mishra, N.; Mohata, M. Expression of complement receptor 3 (CR3) and regulatory protein CD46 on dendritic cells of antiretroviral naïve and treated HIV-1 infected individuals: Correlation with immune activation status. Mol. Immunol. 2018, 96, 83-87. [CrossRef] [PubMed]

341. Festa, L.; Gutoskey, C.J. Induction of interleukin-1ßby human immunodeficiency virus-1 viral proteins leads to increased levels of neuronal ferritin heavy chain, synaptic injury, and deficits in flexible attention. J. Neurosci. 2015, 35, 10550-10561. [CrossRef] [PubMed] 